\title{
Developmental Expression of Platelet-Derived Growth Factor $\alpha$-Receptor in Neurons and Glial Cells of the Mouse CNS
}

\author{
Brahim Nait Oumesmar, Lionel Vignais, and Anne Baron-Van Evercooren \\ Institut National de la Santé et de la Recherche Médicale U134, Laboratoire de Neurobiologie Cellulaire, Moleculaire et \\ Clinique and CJF Laboratoire de la Pathologie de la Myéline, 75651 Paris Cedex 13, France
}

The synthesis of platelet-derived growth factor- $\alpha$ receptor (PDGF- $\alpha \mathrm{R}$ ) is commonly attributed to oligodendrocyte progenitors during late embryonic and postnatal development. However, we recently demonstrated that mature neurons could also synthesize PDGF- $\alpha$ R, emphasizing a larger role for this receptor than previously described. In the present study, to analyze the pattern of PDGF- $\alpha$ R expression during postnatal development of the mouse CNS, we used in situ hybridization and immunohistochemistry on brain and spinal cord tissue sections. We found that, in addition to immature cells of the oligodendrocyte lineage, neurons of various CNS regions express PDGF- $\alpha$ R transcripts and protein as early as postnatal day 1 (P1). Whereas neuronal expression was maintained at all ages, the oligodendroglial expression strongly decreased after
P21. In the adult, PDGF- $\alpha \mathrm{R}$ was detected in very few oligodendrocyte progenitors scattered in the cerebral cortex or in white matter tracts, thus suggesting the presence of PDGF- $\alpha \mathrm{R}$ on $\mathrm{O}-2 \mathrm{~A}^{\text {adult }}$ progenitors. In the mature CNS, PDGF- $\alpha$ R transcripts and protein were mainly localized in neurons of numerous structures, such as the olfactory bulb, cerebral cortex, hippocampus, and brainstem nuclei and in motor neurons of the ventral horn of the spinal cord. The differential expression of PDGF- $\alpha \mathrm{R}$ in oligodendroglia and neurons argues in favor of several roles of PDGF during development.

Key words: platelet-derived growth factor; PDGF $\alpha$-receptor; oligodendrocyte lineage; neurons; CNS development; in situ hybridization; immunohistochemistry
Platelet-derived growth factor (PDGF) was initially described for its potent mitogenic activity on smooth muscle cells, fibroblasts (Ross et al., 1974; Brewitt and Clark, 1988), and glial cells (Westermark and Wasteson, 1976; Besnard et al., 1987). It also mediates other crucial functions during embryonic development (Mercola et al., 1990; Schatteman et al., 1992), tissue repair (Shimokado et al., 1985), chemotactism (Grotendorst et al., 1989; Hosang et al., 1989), extracellular matrix synthesis (Narayanan et al., 1983; Bauer et al., 1985; Chua et al., 1985; Majack et al., 1987), and cytoskeleton rehandling (Mellstrom et al., 1988; Eriksson et al., 1992).

PDGF is encoded by two genes (PDGF-A and PDGF-B) and is active as a disulphide-linked dimer (Antoniades, 1981). Two structurally related PDGF receptors have been identified, a 170 $\mathrm{kDa} \alpha$ receptor (PDGF- $\alpha \mathrm{R}$ ) (Matsui et al., 1989) and a $190 \mathrm{kDa}$ $\beta$ receptor (PDGF- $\beta \mathrm{R}$ ) (Yarden et al., 1988). These receptors belong to the tyrosine kinase receptor family. PDGF- $\alpha$ R can bind both PDGF-A and PDGF-B chains, whereas $\beta$ receptor binds only the PDGF-B chain. The binding of the ligand dimer induces dimerization of the receptor, leading to intracellular tyrosine kinase activity (for review, see Ullrich and Schlessinger, 1990).

Several in vitro studies have reported on the importance of PDGF in the development and differentiation of the oligodendro-

\footnotetext{
Received July 29, 1996; revised Oct. 9, 1996; accepted Oct. 21, 1996.
}

This study was supported by the Myelin Project, the Association pour la Recherche sur la Sclérose en Plaques, and Institut National de la Santé et de la Recherche Médicale. B.N.O. is a fellow of the Société des Amis des Sciences. We are grateful to Dr. N. Baumann for helpful discussions and C. Bachelin for her technical assistance. We thank Prof. C. H. Heldin for the kind gift of the PDGFR-7 antibody and M. C. Nadaud and Dr. H. Villarroya for advice on Western blots.

Correspondence should be addressed to Dr. Anne Baron-Van Evercooren, INSERM U134, Laboratoire de Neurobiologie Cellulaire, Moleculaire et Clinique, 47 Boulevard de l'Hôpital, 75651 Paris Cedex 13, France.

Copyright (C) 1996 Society for Neuroscience $0270-6474 / 96 / 170125-15 \$ 05.00 / 0$ cytes, the myelin-forming cells of the CNS. Oligodendrocytes arise from a bipotential precursor, the oligodendrocyte-type-2 astrocyte, named $\mathrm{O}-2 \mathrm{~A}$, which is able to proliferate and differentiate, under the control of appropriate growth factors, into either mature oligodendrocytes or type-2 astrocytes (Lillien et al., 1988; Noble et al., 1988; Raff et al., 1988; McKinnon et al., 1993). In vitro, the $\mathrm{O}-2 \mathrm{~A}$ cell could be maintained in the cell cycle by the coordinated action of bFGF and PDGF, bFGF upregulating the transcription of the PDGF- $\alpha \mathrm{R}$ (McKinnon et al., 1990). Moreover, PDGF is the only known chemoattractant factor for O-2A progenitors (Armstrong et al., 1990).

In vivo, PDGF-A and -B forms are constitutively produced by neurons within the developing and mature CNS (Sasahara et al., 1991; Yeh et al., 1991) and by type-1 astrocytes in the optic nerve (Richardson et al., 1988; Pringle et al., 1989). These data suggest that neurons, in addition to astrocytes, could regulate targeting, proliferation, and differentiation of oligodendrocyte precursors before myelination (Yeh et al., 1991; Barres et al., 1993). Although oligodendrocyte progenitors have been detected in the rodent embryonic CNS by the expression of DM-20 and PDGF- $\alpha \mathrm{R}$ transcripts, it is unclear whether these two different cell populations (DM-20 ${ }^{+}$and PDGF- $\alpha \mathrm{R}^{+}$) are solely restricted to the oligodendroglial lineage (Pringle et al., 1992; Pringle and Richardson, 1993; Yu et al., 1994; Timsit et al., 1995).

Several studies have failed to detect the expression of PDGF- $\alpha \mathrm{R}$ on neurons during embryonic and early postnatal development (Pringle et al., 1992; Yeh et al., 1993). Nevertheless, we recently reported that PDGF- $\alpha \mathrm{R}$ is mainly localized in mature neurons of the adult mouse CNS (Vignais et al., 1995). Therefore, we hypothesized that PDGF- $\alpha \mathrm{R}$ is predominantly expressed in neurons when myelination is achieved. In the present paper, we analyze the profile of expression of PDGF- $\alpha \mathrm{R}$ transcripts and 
proteins during postnatal development of the mouse CNS. We report a concomitant expression of PDGF- $\alpha \mathrm{R}$ by neurons and immature oligodendroglial cells and a drop in the oligodendroglial expression when myelination is fully accomplished.

\section{MATERIALS AND METHODS}

Animals and tissue processing. Mice of the OF1 strain were purchased from IFFA-CREDO (Oncins, France) and were 1, 7, 15, 21, 30, and 120 postnatal days old $(\mathrm{P})$. The mice $(n=5$ for each age studied) were perfused intracardially with a solution of $4 \%$ paraformaldehyde in $0.1 \mathrm{M}$ PBS, pH 7.4. Spinal cords and brains were removed and immersed overnight in the same fixative. They were then soaked overnight in a solution of $20 \%$ sucrose in $0.1 \mathrm{M}$ PBS. Brains and spinal cords were finally embedded in OCT (Miles, Elkhart, IN), frozen in isopentane $\left(-60^{\circ} \mathrm{C}\right)$, and stored at $-40^{\circ} \mathrm{C}$ until use. Sagittal sections $(10 \mu \mathrm{m}$ thick) were cut on a Reichert-Jung cryostat (Leica, Germany) and collected on RNase-free gelatin-coated slides. Free-floating sagittal sections (30 $\mu \mathrm{m}$ thick) were also cut on a vibratome (Leica), collected in 24-well culture tissue plates containing $0.1 \mathrm{M}$ sterile PBS, and immediately processed for in situ hybridization and immunohistochemistry (IHC) procedures.

Western blot analysis. Brains of P1, P7, and P120 mice were homogenized in Tris-saline buffer, $\mathrm{pH} 6.8$, containing $0.5 \%$ deoxycholate, $0.5 \%$ Triton $\mathrm{X}-100,2 \mu \mathrm{g} / \mathrm{ml}$ aprotinin, and $1 \mathrm{~mm}$ phenylmethyl sulfonyl fluoride and spun at $150,000 \times g$ for $10 \mathrm{~min}$. Solubilized material was boiled for $10 \mathrm{~min}$ in a buffer containing 3\% SDS and 5\% dithiothreitol, and proteins $(20-50 \mu \mathrm{g})$ were separated by SDS-PAGE (7\% acrylamide gel). After electrophoresis, proteins were transferred to nitrocellulose membrane. The membranes were then Ponceau-stained to verify equal loading and transfer of proteins. After destaining, the membranes were incubated in blocking buffer (20 mM Tris, $150 \mathrm{mM} \mathrm{NaCl}, 0.05 \%$ Tween-20, and $5 \%$ powdered nonfat milk, $\mathrm{pH}$ 7.4) for $2 \mathrm{hr}$ at room temperature. The membranes were then washed three times in $0.1 \mathrm{M}$ PBS (10 min each) and incubated for $2 \mathrm{hr}$ in the blocking buffer with anti-mouse PDGF- $\alpha \mathrm{R}$ antibody (UBI, Lake Placid, NY) at the working dilution of 1:500. After incubation with the primary antibody, the blot was washed with PBS and incubated for $2 \mathrm{hr}$ with horseradish peroxidase (HRP)-conjugated swine anti-rabbit IgG antibody (1:500 dilution; Dakopatts, Denmark). Labeled bands were revealed in $0.1 \mathrm{M}$ Tris- $\mathrm{HCl}, \mathrm{pH} 7.6$, containing $0.03 \% \mathrm{DAB}$ (Dakopatts), $0.5 \% \mathrm{NiCl}_{2}$, and $0.02 \% \mathrm{H}_{2} \mathrm{O}_{2}$. The membrane was washed in water and air-dried. In this Western immunoblot analysis, cellular protein preparation from mouse $3 \mathrm{~T} 3$ mouse cells (UBI) was used as a positive antigen control.

IHC. In this study, the following antibodies were used: a rabbit polyclonal anti-mouse PDGF- $\alpha \mathrm{R}$ antibody raised against the $110 \mathrm{C}$-terminal amino acid residues of the murine PDGF- $\alpha \mathrm{R}$ (UBI), an antibody that is specific for the $\alpha$ receptor and does not cross-react with the $\beta$ receptor (Cheng and Mattson, 1995); a rabbit polyclonal anti-PDGF- $\alpha \mathrm{R}$ antibody (PDGFR-7, a kind gift from Prof. C. H. Heldin, Ludwig Institute for Cancer Research, Uppsala, Sweden) raised against the cytoplasmic domain of human PDGF- $\alpha \mathrm{R}$ and specific to the PDGF- $\alpha \mathrm{R}$ (Eriksson et al., 1992); a monoclonal anti-GFAP (mouse IgG1, Dakopatts) to stain astrocytes; a rat monoclonal anti-F4/80 (rat IgG2b, Serotec, Oxford, UK), which specifically recognizes activated microglia and macrophages in the mouse CNS (Austyn and Gordon, 1981); a mouse Rip monoclonal antibody (mouse IgG1, a kind gift from Dr. B. Friedman), which labels differentiated oligodendrocytes (Friedman et al., 1989; Jhaveri et al., 1992); an anti-MAP2a + b monoclonal antibody, used to identify neurons (mouse IgG1, Sigma, St. Louis, MO); and a mouse monoclonal anti-PSANCAM (mouse IgM, a kind gift from Dr. G. Rougon, Marseille, France) raised specifically against the $\alpha 2$-8-linked $N$-acetylneuraminic acid units of the embryonic form of N-CAM (Rougon et al., 1986), which was used as a marker of neural stem cells. The identification of the cell types expressing PDGF- $\alpha \mathrm{R}$ was assessed by double-immunostaining procedures using the polyclonal anti-PDGF- $\alpha \mathrm{R}$ with each of the antibodies described above. Working dilutions were as follows: anti-mouse PDGF$\alpha \mathrm{R}, 1: 200$; PDGFR-7 antibody, 1:200; Rip antibody, 1:2; anti-GFAP, 1:100; anti-F4/80, 1:40; anti-MAP2, 1:100; anti-PSA-NCAM, 1:100.

For IHC, vibratome sections were rinsed three times in $0.1 \mathrm{M}$ PBS (5 min each) and incubated with $10 \%$ normal swine serum (Life Biotechnologies, Gaithersburg, MD) in $0.1 \mathrm{M}$ PBS for $30 \mathrm{~min}$ to reduce nonspecific staining. Sections were then incubated overnight at $4^{\circ} \mathrm{C}$ with constant agitation, in a double-immunolabeling procedure, with the primary antibodies diluted in PBS containing 10\% normal swine serum. They were then rinsed three times in PBS (10 min each) and incubated for $2 \mathrm{hr}$ with the appropriate secondary antibodies: swine FITC-conjugated anti-rabbit IgG (Dakopatts), goat TRITC-conjugated anti-mouse IgG1 (Southern Biotechnology, Birmingham, AL), goat FITC-conjugated anti-mouse IgM (Fab fragments, Tebu, France), or goat TRITC-conjugated anti-rat IgG (Silenus, Hawthorn, Australia). These antibodies were all diluted 1:100 in PBS containing $10 \%$ normal swine serum. Sections were finally rinsed in PBS, mounted on gelatin-coated slides, air-dried, and mounted with Vectashield mounting medium (Vector Laboratories, Burlingame, CA). Slides were observed under fluorescence on a DMRB Leitz microscope. For the PDGF- $\alpha \mathrm{R}$ IHC staining, we also used an immunoperoxidase procedure as described above with additional steps: incubation for $20 \mathrm{~min}$ in $0.3 \% \mathrm{H}_{2} \mathrm{O}_{2}$ in $0.1 \mathrm{M}$ PBS before saturation and incubation with the primary and secondary antibody (HRP-conjugated swine anti-rabbit IgG, 1:100 dilution, Dakopatts). Peroxidase histochemistry was performed in 0.05 м Tris- $\mathrm{HCl}, \mathrm{pH} 7.3$, containing $0.03 \%$ DAB (Dakopatts), $0.5 \%$ $\mathrm{NiCl}_{2}$, and $0.003 \% \mathrm{H}_{2} \mathrm{O}_{2}$ and was stopped in water. Floating sections were mounted as described above, and slides were dehydrated in ethanol, clarified in xylene, and mounted in Eukitt (Kindler GmbH, Freiburg, Germany). In each double-immunolabeling experiment, we systematically performed control single labeling, using each primary antibody separately. Control sections were made by omitting primary antibodies and were always free of labeling (data not shown).

In situ hybridization. In situ hybridization (ISH) was performed as described previously (Vignais et al., 1995) using a digoxigenin-labeled oligonucleotide probe complementary to the murine PDGF- $\alpha \mathrm{R}$ (30 mer, 5'-GACAATGACAATCACCAACAGCACCAACAC- $\left.3^{\prime}\right)$. This antisense DNA single-stranded oligonucleotide probe $5^{\prime}$ - and $3^{\prime}$-digoxigenin end-labeled was purchased from R\&D Systems (Abingdon, UK). Freefloating sections were briefly washed in PBS, transferred into prehybridization solution $(50 \%$ deionized formamide, $4 \times$ SSC, and $1 \times$ Denhardt's solution) for $1 \mathrm{hr}$ at $37^{\circ} \mathrm{C}$, and washed in $4 \times \mathrm{SSC}$ for $10 \mathrm{~min}$. Sections were then incubated in the hybridization buffer $(50 \%$ deionized formamide, $4 \times \mathrm{SSC}, 1 \%$ Denhardt's solution, $5 \%$ dextran sulfate, $100 \mu \mathrm{g} / \mathrm{ml}$ yeast t-RNA, and $250 \mu \mathrm{g} / \mathrm{ml}$ sheared herring salmon sperm DNA) containing the digoxigenin-labeled probe at the final concentration of $5 \mathrm{ng} / \mu \mathrm{l}$ for $16 \mathrm{hr}$ at $42^{\circ} \mathrm{C}$. Thereafter, they were washed, respectively, in $2 \times \mathrm{SSC}$ for $1 \mathrm{hr}, 1 \times \mathrm{SSC}$ for $1 \mathrm{hr}, 1 \times \mathrm{SSC}$ at $37^{\circ} \mathrm{C}$ for $30 \mathrm{~min}, 1 \times \mathrm{SSC}$ for $30 \mathrm{~min}$ at room temperature and, finally, in $0.5 \times \mathrm{SSC}$ for $30 \mathrm{~min}$. Before immunological detection of hybridized probes, sections were washed in buffer A (100 mM Tris- $\mathrm{HCl}, 150 \mathrm{~mm} \mathrm{NaCl}, \mathrm{pH} 7.5)$ and then preincubated in the same buffer containing $2 \%$ normal sheep serum and $0.3 \%$ Triton $\mathrm{X}-100$ for $30 \mathrm{~min}$. This was followed by incubation overnight at $4^{\circ} \mathrm{C}$ with the anti-digoxigenin alkaline phosphatase (AP)-conjugated antibody (FAB fragment, Boehringer Mannheim, Mannheim, Germany) diluted at 1:500 in buffer A containing $0.1 \%$ Triton X-100 and 1\% normal sheep serum. After the incubation, sections were rinsed in buffer A (3 times, 10 min each) and twice (10 min each) in buffer B (100 mM Tris- $\mathrm{HCl}, 100 \mathrm{~mm}$ $\left.\mathrm{NaCl}, 50 \mathrm{~mm} \mathrm{MgCl}_{2}, \mathrm{pH} 9.5\right)$. The AP activity was detected using $45 \mu \mathrm{l}$ of nitroblue tetrazolium solution, $35 \mu \mathrm{l}$ of X-phosphate (5-bromo-4-chloro3 -indolyl-phosphate), and $0.24 \mathrm{mg} / \mathrm{ml}$ Levamisole (Sigma) in buffer B. The chromogen reaction was monitored for $2-5 \mathrm{hr}$ and stopped with a solution containing $100 \mathrm{~mm}$ Tris- $\mathrm{HCl}$ and $0.1 \mathrm{~mm}$ EDTA, $\mathrm{pH} 7.5$. Sections were washed extensively, mounted on gelatin-coated slides, air-dried, and coverslipped in 50\% PBS/50\% glycerol. No specific labeling was observed when the antisense probe was omitted from the hybridization solution. A control procedure, either preincubation with $20 \mu \mathrm{g} / \mathrm{ml}$ RNase A (Boehringer Mannheim) for $30 \mathrm{~min}$ at $37^{\circ} \mathrm{C}$ or competition with a 40 -fold excess of the unlabeled antisense probe in the hybridization mixture, abolished all specific mRNA signal.

\section{RESULTS \\ Immunoblot analysis and specificity of anti-mouse PDGF- $\alpha$ R antibody}

Western blot analysis was performed on total protein extracts from P1, P7, and P120 mouse brain to demonstrate the specificity of the anti-mouse PDGF- $\alpha \mathrm{R}$ antibody. In Western immunoblotting, 170 and $140 \mathrm{kDa}$ protein bands immunoreactive with the anti-mouse PDGF- $\alpha$ R antibody were detected in homogenates from P1 (Fig. 1, lane 3), P7 (Fig. 2, lane 2), and P120 (Fig. 1, lane 1) mouse brain as well as in cellular protein preparation from mouse 3 T3 cells (Fig. 1, lane 4), used as a positive antigen control. These two immunoreactive bands correspond to the PDGF- $\alpha$ R 


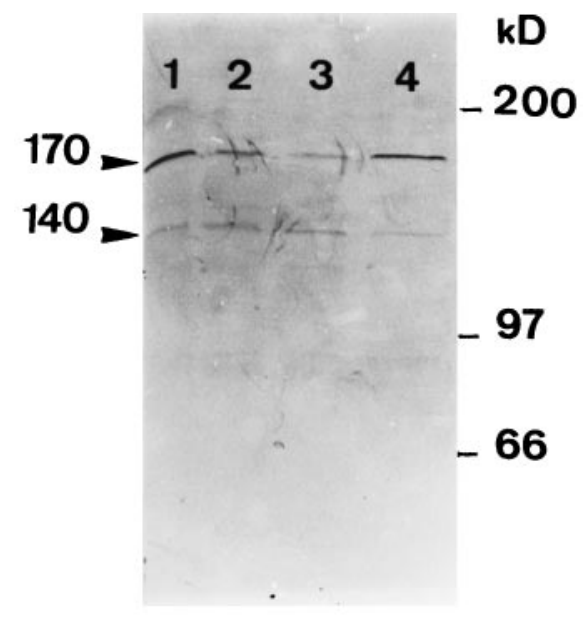

Figure 1. Western blot characterization of anti-mouse PDGF $\alpha$-R, antibody in protein extracts from $\mathrm{P} 1, \mathrm{P} 7$, and adult mouse brain. The antimouse PDGF- $\alpha$ R recognizes 170 and $140 \mathrm{kDa}$ protein bands, equivalent to the estimated size of the mature form and the precursor form, respectively, of the PDGF $\alpha$-R in adult (lane 1), P7 (lane 2), and P1 (lane 3) mouse brain, and mouse $3 \mathrm{~T} 3$ cells (lane 4 ), used as a positive antigen control. The relative migration positions of the molecular weight standards (myosin, 200,000; phosphorylase b, 97,000; bovine serum albumin, $66,000)$, run in parallel, are indicated.

species that had been identified previously with the PDGF-R7 antibody (Eriksson et al., 1992; Nishiyama et al., 1996). The 140 $\mathrm{kDa}$ band may represent the precursor form of the PDGF- $\alpha \mathrm{R}$ as demonstrated by pulse-chase analysis by Eriksson et al. (1992).

\section{Expression of PDGF- $\alpha R$ in the newborn mouse brain}

The expression of PDGF- $\alpha \mathrm{R}$ was analyzed by IHC and nonradioactive ISH during postnatal development of the mouse CNS. In the newborn mouse brain, the immunohistological expression of PDGF- $\alpha \mathrm{R}$ was widely distributed (Fig. 2). At this age, most brain structures showed intense PDGF- $\alpha \mathrm{R}$ immunoreactivity. In the cerebral cortex, immunoreactivity was localized on neurites and in neuronal-like cell soma (Fig. $2 A, B$ ) and in well characterized neuronal structures, such as the hippocampus (see Table 1). The presumptive white matter was also strongly immunoreactive for PDGF- $\alpha$ R. The corpus callosum and fibers of the striatum were immunolabeled with the anti-PDGF- $\alpha \mathrm{R}$ antibody (Fig. 2C). This expression of PDGF- $\alpha \mathrm{R}$ was observed only on unmyelinated fibers throughout the first postnatal week and decreased with myelination. The expression of PDGF- $\alpha \mathrm{R}$ was also observed in the periventricular areas, such as the subventricular zone (SVZ) of the lateral ventricle (Fig. $2 D$ ). In these regions, the immunoreactivity was localized on round cells clustered around the ventricle. In sagittal sections, this expression spread out to ependy$\mathrm{mal} / \mathrm{subependymal} \mathrm{layer} \mathrm{of} \mathrm{the} \mathrm{olfactory} \mathrm{ventricle} \mathrm{(not} \mathrm{shown).} \mathrm{At}$ $\mathrm{P} 1$, the intense immunoreactivity for PDGF- $\alpha \mathrm{R}$ made the immunological identification of cell types expressing PDGF- $\alpha \mathrm{R}$ difficult. However, at P7, neurons of the cerebral cortex stained with the anti-MAP2 antibody expressed PDGF- $\alpha \mathrm{R}$ (Fig. 6E,F). The neuronal expression of PDGF- $\alpha \mathrm{R}$ was clearly evidenced, as early as $\mathrm{P} 1$, in the cerebellum (Fig. $3 A, B$ ) and the hippocampus (not shown).

\section{Developmental expression of PDGF- $\alpha$ R in the cerebellum}

The developmental expression of PDGF- $\alpha \mathrm{R}$ is illustrated for the cerebellum from P1 to P15 (Fig. 3). In the P1 cerebellum,

\begin{tabular}{|c|c|c|c|c|}
\hline \multirow[b]{2}{*}{ Location } & \multicolumn{4}{|l|}{ Age } \\
\hline & $\mathrm{P} 1$ & P7 & P15 & $\mathrm{P} 120$ \\
\hline \multicolumn{5}{|l|}{ Olfactory system } \\
\hline Periglomerular layer & +++ & +++ & +++ & +++ \\
\hline Internal granular layer & +++ & +++ & ++ & + \\
\hline Mitral cell layer & + & ++ & +++ & +++ \\
\hline Olfactory ventricle & +++ & +++ & ++ & ++ \\
\hline Anterior olfactory nucleus & +++ & +++ & +++ & +++ \\
\hline Olfactory tubercle & +++ & +++ & +++ & +++ \\
\hline Cerebral cortex & +++ & +++ & ++ & ++ \\
\hline Striatum & - & - & - & - \\
\hline Globus pallidus & nd & +++ & ++ & ++ \\
\hline \multicolumn{5}{|l|}{ Hippocampus } \\
\hline CA1-CA4 & +++ & +++ & ++ & ++ \\
\hline Dentate gyrus & +++ & +++ & ++ & ++ \\
\hline Subiculum & nd & nd & ++ & ++ \\
\hline Thalamus & +++ & +++ & ++ & ++ \\
\hline \multicolumn{5}{|l|}{ Substantia nigra } \\
\hline Reticular & nd & nd & ++ & ++ \\
\hline Compact & nd & nd & ++ & ++ \\
\hline Colliculus & nd & nd & ++ & ++ \\
\hline \multicolumn{5}{|l|}{ Cerebellum } \\
\hline Molecular layer & - & - & - & - \\
\hline Purkinje cell layer & ++ & ++ & ++ & +++ \\
\hline Granule cell layer & +++ & +++ & + & - \\
\hline Cerebellar nucleus & nd & nd & ++ & +++ \\
\hline \multicolumn{5}{|l|}{ Pons-medulla } \\
\hline Facial nucleus & nd & nd & ++ & ++ \\
\hline Vestibular nucleus & nd & nd & ++ & ++ \\
\hline Trigeminal nucleus & nd & nd & ++ & ++ \\
\hline Other nucleus & nd & nd & ++ & ++ \\
\hline \multicolumn{5}{|l|}{ Spinal cord } \\
\hline Dorsal horn (layers I and II) & nd & nd & ++ & ++ \\
\hline Motoneurons (ventral horn) & nd & nd & ++ & +++ \\
\hline
\end{tabular}

Relative immunoreactivity was evaluated on brain and spinal cord tissue sections, processed for immunohistochemistry as described in Materials and Methods. The relative immunoreactivity for PDGF- $\alpha \mathrm{R}$ was subjectively rated as follows: - , absent; + , low; ++ , moderate; +++ , high; nd, not determined.

PDGF- $\alpha \mathrm{R}$ immunoreactivity was noted in the Purkinje and granule cell layer, whereas the external germinal layer that gives rise to the granule cells was not stained at any of the ages studied (Fig. $3 A, B)$. Fibers of the presumptive white matter, which at this stage are still unmyelinated, were strongly immunolabeled. At P7, the pattern of PDGF- $\alpha \mathrm{R}$ immunostaining had a similar profile to P1, although with a few modifications. The expression of PDGF- $\alpha \mathrm{R}$ by Purkinje cells was more obvious at this time of development. $\mathrm{PDGF}-\alpha \mathrm{R}$ immunoreactivity was localized in the soma and dendritic tree of these cells, which formed a pluricellular layer. The presumed descending granule cells from the external germinal layer as well as the internal granule cell layer were also highly immunoreactive for the PDGF- $\alpha \mathrm{R}$ (Fig. 3C,D). At P15 (Fig. $3 E, F)$, the expression of PDGF- $\alpha \mathrm{R}$ decreased compared with $\mathrm{P} 1$ and P7. Purkinje cells remained highly immunoreactive for PDGF- $\alpha \mathrm{R}$, whereas the immunolabeling in the granule cell layer decreased considerably and became undetectable in the mature cerebellum (see Fig. 9A,B). The staining was seen throughout the cytoplasm and was also evident in the branches of the dendritic 

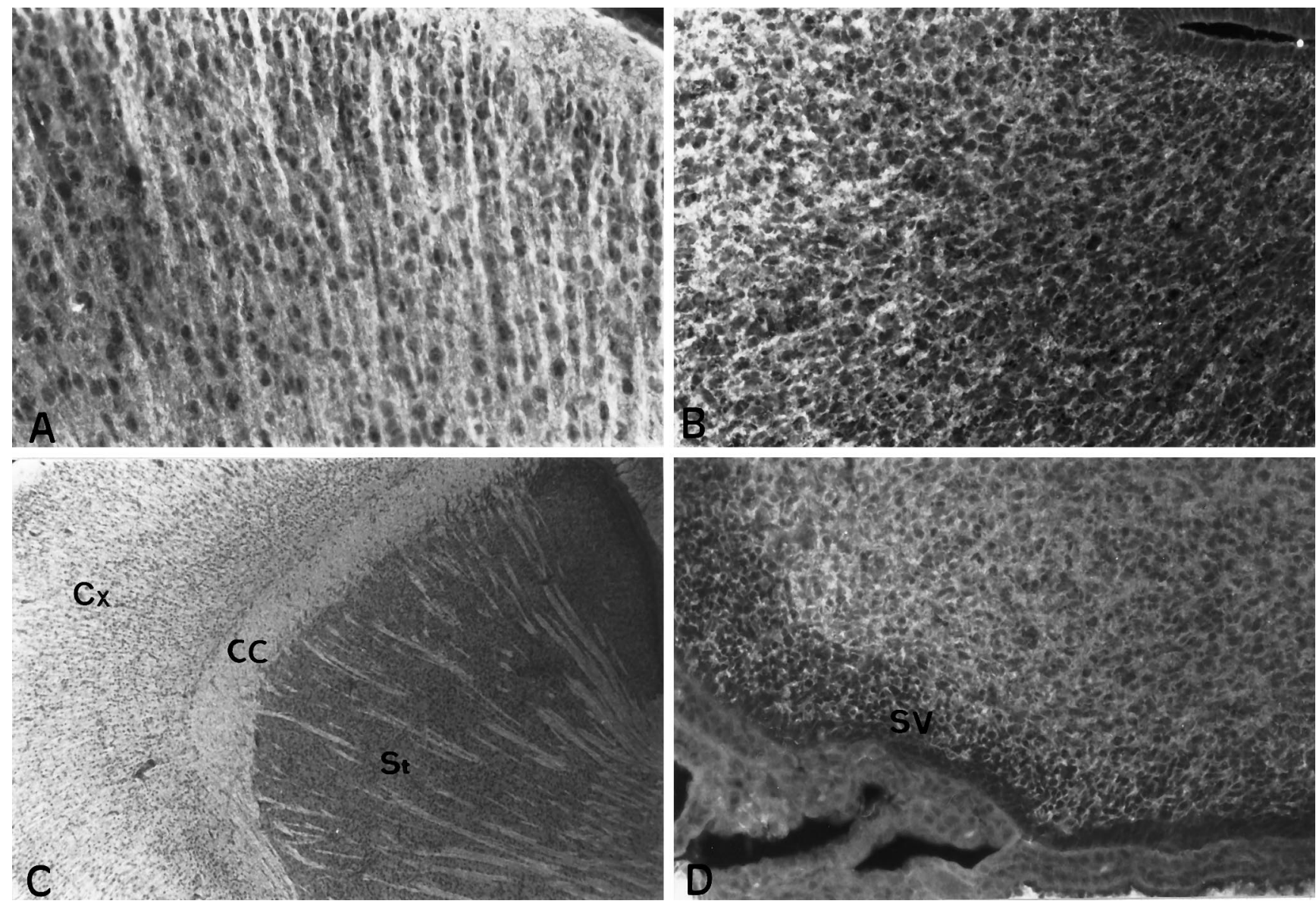

Figure 2. Expression of PDGF- $\alpha \mathrm{R}$ in the P1 mouse brain. $A$, Immunodetection of PDGF- $\alpha \mathrm{R}$ protein in the prefrontal cortex. PDGF- $\alpha \mathrm{R}$ is localized on neurites and neuronal cell bodies. $B$, Immunoreactivity for PDGF- $\alpha \mathrm{R}$ in the entorhinal cortex. PDGF- $\alpha \mathrm{R}$ is widely expressed in the cerebral cortex $(C x)$ as well as in presumptive white matter structures, as illustrated for the corpus callosum $(C C)$ and fibers of the striatum $(S t)$ in $C$. Striatal neurons are not stained with the polyclonal anti-PDGF- $\alpha$ R. $D$, Immunostaining of cells of the periventricular zone of the lateral ventricle. Magnification: $A$, $B, D$, $200 \times ; C, 50 \times$.

tree of the Purkinje cells, their axons remaining unlabeled (Fig. $3 F)$. At P15, labeling of the fiber tracts disappeared and a new PDGF- $\alpha \mathrm{R}^{+}$cell type was visualized within the cerebellum white matter (Fig. $3 E, F$ ). These positive cells were probably immature cells of the oligodendrocyte lineage. Their appearance seems to be correlated with the active myelination that occurs at this time in the cerebellum (Foran and Peterson, 1992). The developmental evolution of PDGF- $\alpha \mathrm{R}$ immunoreactivity in the mouse cerebellum showed a transient expression of the PDGF- $\alpha \mathrm{R}$ by granule cells coinciding with their genesis from the external germinal layer and their migration toward the molecular and Purkinje cell layer (Altman, 1972).

\section{Neurons express PDGF- $\alpha R$ transcripts during postnatal development}

To verify whether neurons could synthesize the PDGF- $\alpha \mathrm{R}$, the transcripts of PDGF- $\alpha \mathrm{R}$ were detected by nonradioactive in situ hybridization on free-floating brain and spinal cord sections from $\mathrm{P} 1$ to adulthood. PDGF- $\alpha \mathrm{R}$ transcripts were detected in neurons as early as P1 (not shown). At P15, a strong signal for PDGF- $\alpha \mathrm{R}$ transcripts was found in most neuronal populations (Fig. 4). For instance, cortical neurons of the prefrontal cortex exhibited a strong in situ hybridization signal (Fig. 4A). High magnification of this labeling clearly showed the localization of PDGF- $\alpha \mathrm{R}$ on neurons, identified by their large size and their location (Fig. $4 B$ ).
Neurons of the hippocampal formation also expressed PDGF- $\alpha$ R mRNA (Fig. 4C); likewise, a similar pattern of PDGF- $\alpha$ R transcript expression was found at P1 and P7 (not shown). In white matter structures, such as the corpus callosum or the fimbria, the expression of PDGF- $\alpha$ R mRNA could be visualized in small glial cells aligned along the fiber tracts (Fig. $4 C$ ). These cells belonged to the oligodendrocyte lineage, as reported previously (Pringle et al., 1992; Pringle and Richardson, 1993; Yeh et al., 1993). In P15 mouse spinal cord, motoneurons expressed PDGF- $\alpha \mathrm{R}$ transcripts as did glial cells (Fig. $4 D, E$ ). In adjacent sections, PDGF- $\alpha \mathrm{R}$ protein was localized in the same cell types by IHC using the anti-PDGF- $\alpha$ R antibody (Fig. $4 F$ ). The expression of PDGF- $\alpha \mathrm{R}$ in motoneurons was first observed around P15 and persisted in the mature CNS. Therefore, these results seem to demonstrate that a great majority of CNS neurons express PDGF- $\alpha \mathrm{R}$ during postnatal development.

\section{PDGF- $\alpha R$ is expressed by oligodendrocyte progenitor cells}

From P1 to P7, progenitor cells clustered around periventricular zones such as the subventricular zone of the lateral ventricle and were immunolabeled with the polyclonal anti-PDGF- $\alpha \mathrm{R}$ antibody (Fig. 1D). From P7 to P21, the thickness of this zone decreased in correlation with the emergence of immature cells of the oligodendrocyte lineage in other locations, such as the cerebral cortex (Fig. 

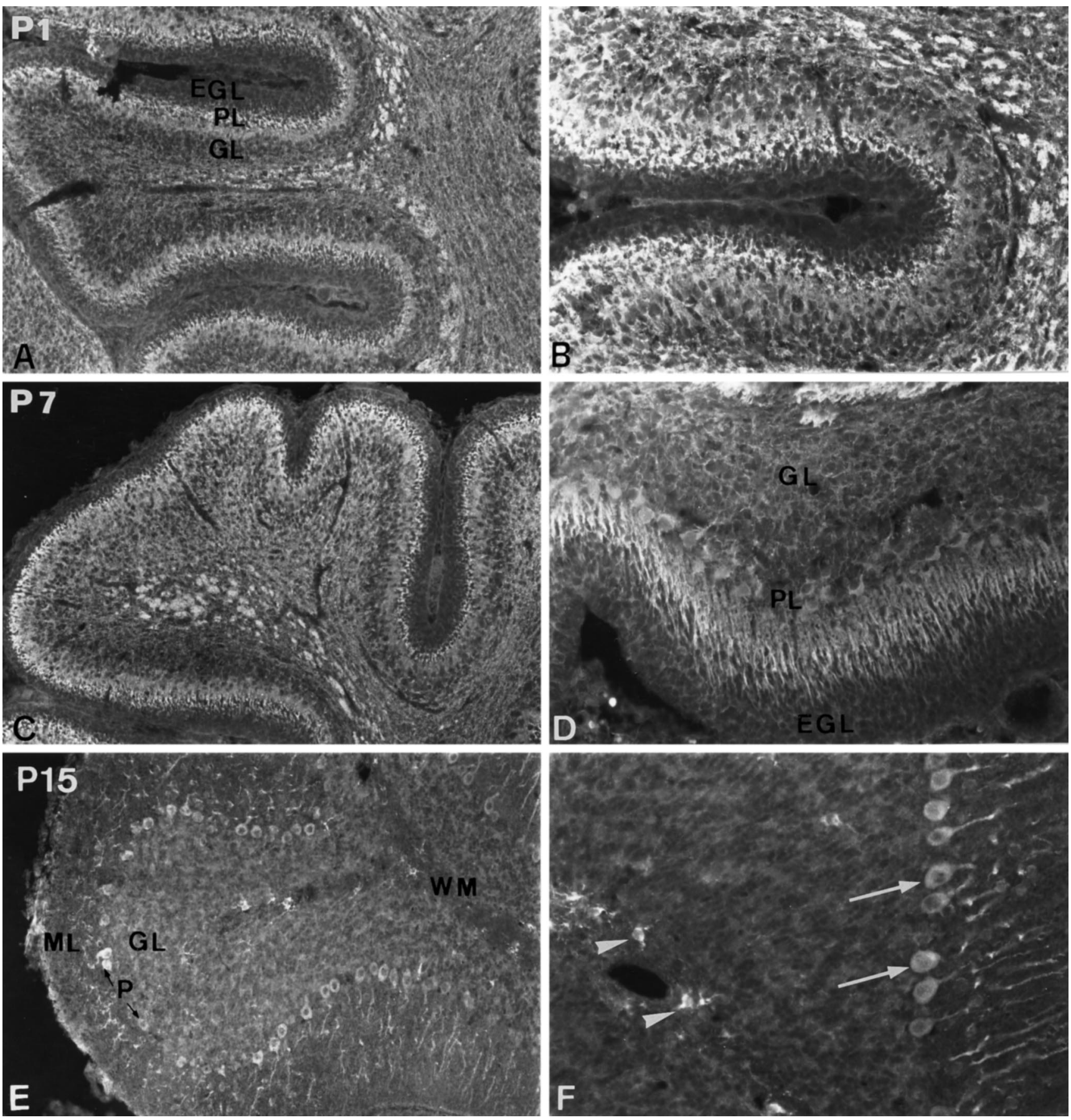

Figure 3. Evolution of PDGF- $\alpha \mathrm{R}$ immunoreactivity in the developing cerebellum. Immunodetection of PDGF- $\alpha \mathrm{R}$ in the cerebellum at P1 ( $A$, $B$ ), $\mathrm{P} 7$ $(C, D)$, and $\mathrm{P} 15(E, F)$. PDGF- $\alpha \mathrm{R}$ immunoreactivity is detected in the Purkinje cell layer, the granule cell layer, and the presumptive white matter $(A)$. High-magnification view showing PDGF- $\alpha$ R immunoreactivity on Purkinje and granule cells. Note the lack of expression in the external germinal layer $(B)$. The expression of PDGF- $\alpha \mathrm{R}$ is also widely distributed in the P7 cerebellum $(C)$. High-magnification view of immunostained Purkinje and granule cells $(D)$. At this period of development, the protein is well evidenced in the Purkinje cell soma and dendrites. At P15, PDGF- $\alpha \mathrm{R}$ immunoreactivity is considerably decreased in the granule cell layer and is not detected on white matter fibers $(E, F)$. The expression is always observed in the soma and dendritic tree of Purkinje cells (arrows in $F$ ) and in oligodendrocyte progenitors (arrowheads in $F$ ). Magnification: $A, C, E, 100 \times ; B, D, F, 200 \times . E G L$, External germinal layer; $M L$, molecular layer; $P L$, Purkinje cell layer; $G L$, granule cell layer; $W M$, white matter.

$5 A, C)$ and the thalamus (Fig. $5 E$ ). During the period of active myelination (P15-P21), cells belonging to the oligodendrocyte lineage were strongly immunolabeled in white matter structures, like the corpus callosum. These positive cells with several processes spread out from the corpus callosum to the cerebral cortex, suggesting their genesis and radial migration from the SVZ (Fig.
$5 A, B)$. In the cerebral cortex, many immunolabeled immature cells of the oligodendrocyte lineage with several processes were detected along PDGF- $\alpha \mathrm{R}^{+}$neurites (Fig. 5C). However, PDGF- $\alpha \mathrm{R}$ immunoreactivity was always stronger in oligodendroglial cells than in neurons. The concomitant expression of PDGF- $\alpha \mathrm{R}$ by neurons and glial cells belonging to the oligoden- 

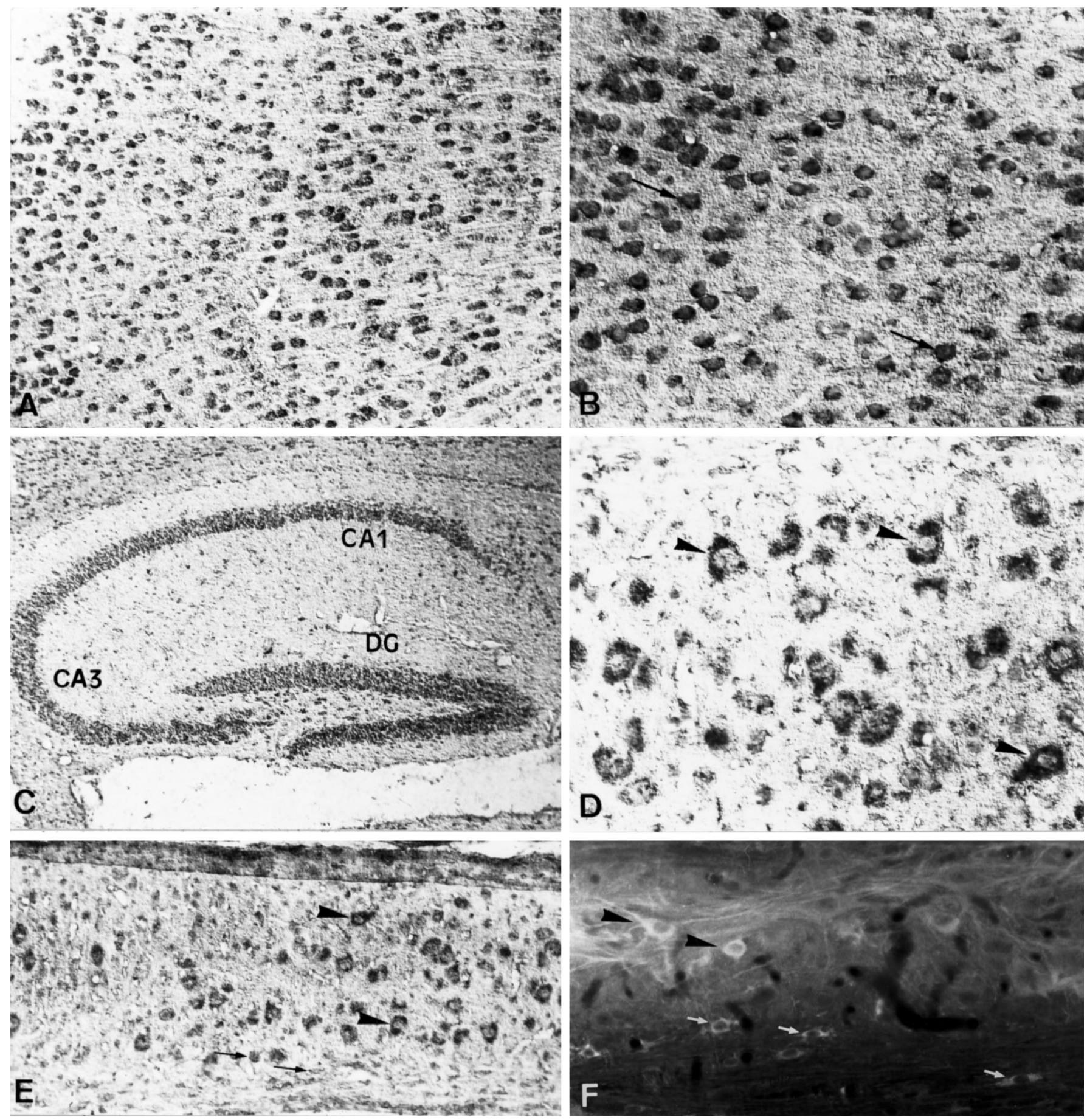

Figure 4. In situ hybridization and IHC of PDGF- $\alpha \mathrm{R}$ on $\mathrm{P} 15$ brain and spinal cord tissue sections. Expression of PDGF- $\alpha \mathrm{R}$ transcripts in the cerebral cortex $(A)$. High-magnification view of the hybridization signal showing the localization of PDGF- $\alpha \mathrm{R}$ mRNA in the soma of cortical neurons (arrows in $B)$. Detection of PDGF- $\alpha$ R transcripts in the hippocampus $(C)$ and in motoneurons (arrowheads) of the spinal cord $(D)$. Longitudinal spinal cord section, hybridized with the digoxigenin-labeled antisense probe complementary to murine PDGF- $\alpha \mathrm{R}$, showing the localization of the transcripts in motoneurons (arrowheads) and oligodendrocyte precursors (arrows; $E$ ). Adjacent section immunolabeled with the anti-PDGF- $\alpha \mathrm{R}$ antibody $(F)$. Note that motoneurons and immature cells of the oligodendrocyte lineage express PDGF- $\alpha \mathrm{R}$ transcripts and protein. $C A 1, C A 3$, Hippocampal fields; $D G$, dentate gyrus. $A-D$, $E$, Bright-field and phase-contrast; $F$, indirect immunofluorescence. Magnification: $A, C, E, F, 124 \times ; B, D, 248 \times$

drocyte lineage was clearly evidenced at this period of development, as observed in the subiculum (Fig. 5D). At P21, the immunological expression of PDGF- $\alpha \mathrm{R}$ by immature cells of the oligodendrocyte lineage extended to most of the CNS regions, such as the thalamus (Fig. $5 E$ ) and cerebellar white matter (Fig. $5 F)$. These PDGF- $\alpha \mathrm{R}^{+}$cells displayed common morphological features of premyelinating oligodendrocytes. By double IHC, combining the anti-PDGF- $\alpha \mathrm{R}$ antibody with cell-specific markers such as Rip, anti-GFAP, anti-F4/80, or anti-MAP2 antibodies, which recognize differentiated oligodendrocytes, astrocytes, microglia, and neurons, respectively, immunocolocalization with neither F4/80 (not shown) MAP2 nor GFAP (Fig. 6C,D) was ob- 

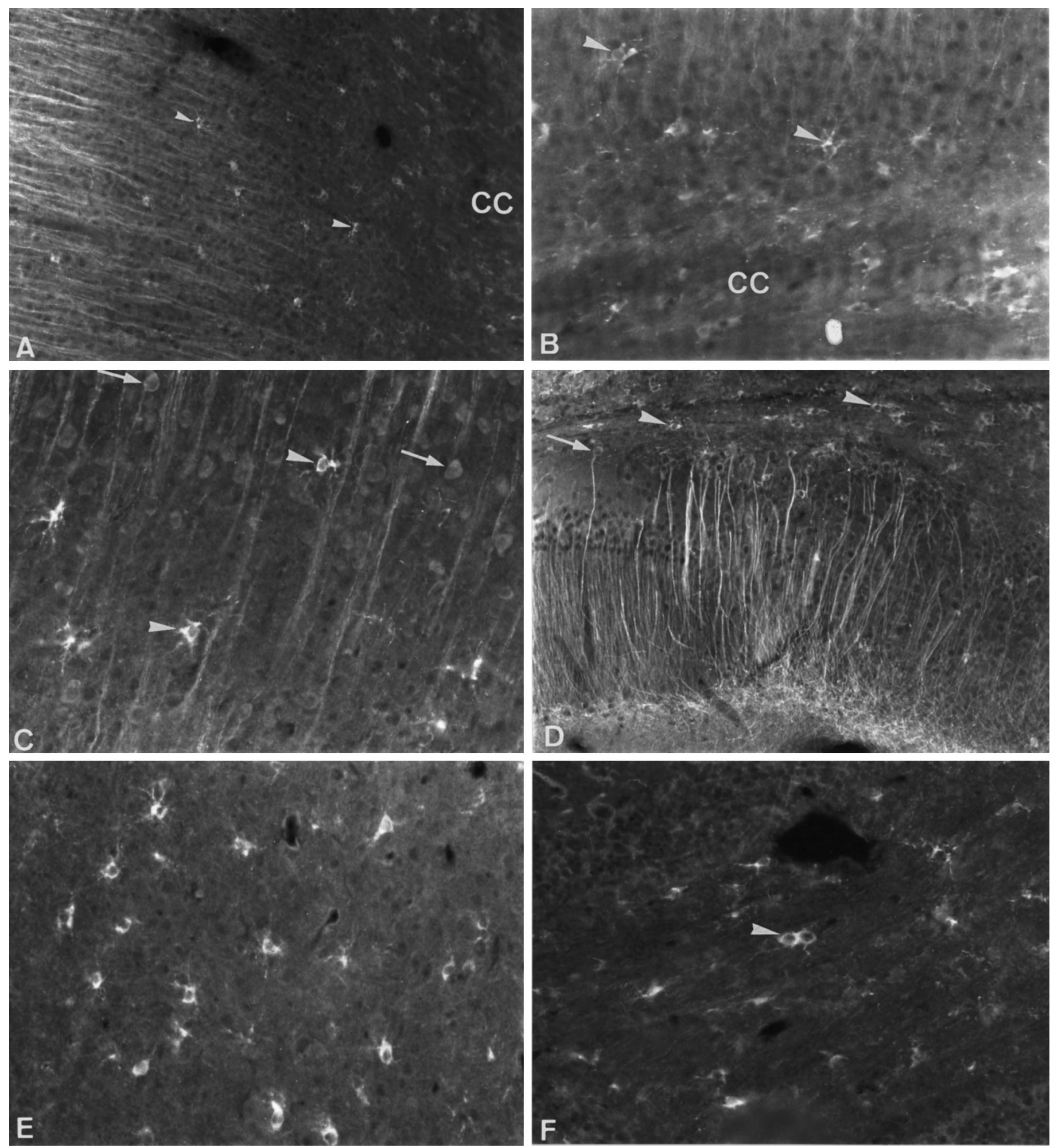

Figure 5. Expression of PDGF- $\alpha \mathrm{R}$ by immature oligodendrocytes in the P21 mouse brain. Spreading of PDGF- $\alpha$ R-positive cells (arrowheads), belonging to progenitor stages of the oligodendrocyte lineage, from the corpus callosum $(C C)$ to the cerebral cortex $(A)$. High-power view showing the morphology of these PDGF- $\alpha$ R-positive cells in the corpus callosum (B). View of the cerebral cortex, showing the concomitant expression of PDGF- $\alpha$ R by neurons (arrows) and immature cells of the oligodendrocyte lineage (arrowheads) extending several processes in contact with PDGF- $\alpha$ R-positive neurites $(C)$. Expression of PDGF- $\alpha \mathrm{R}$ by neurons (arrow) and oligodendroglial cells (arrowheads) in the subiculum $(D)$. Oligodendrocyte progenitors, stained with the anti-PDGF- $\alpha \mathrm{R}$ antibody, in the thalamus $(E)$ and in cerebellar white matter (arrowhead in $F$ ). Magnification: $A, D, 124 \times ; B, C, E, F, 248 \times$. 

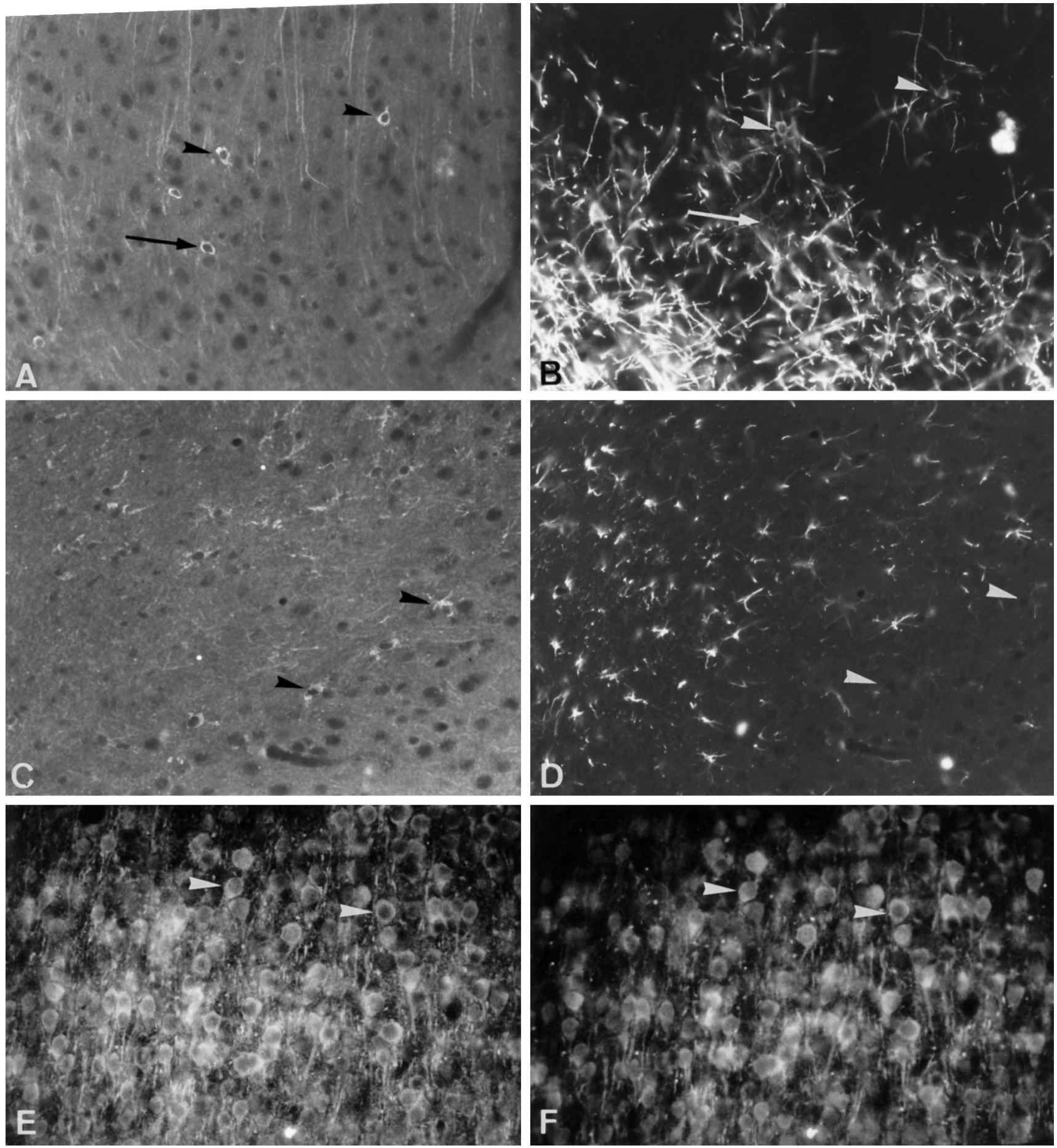

Figure 6. Immunocharacterization of the cell types expressing PDGF- $\alpha$ R. Double immunostaining with anti-PDGF- $\alpha \mathrm{R}(A)$ and Rip $(B)$ on P21 sagittal brain section. PDGF- $\alpha$ R-positive cells (arrowheads in $A$ ) are weakly stained with the Rip antibody $(B)$. Often, there is not strict colocalization between PDGF- $\alpha$ R and Rip expression (arrow), suggesting that these single-labeled cells could be immature cells of the oligodendrocyte lineage. P21 sagittal brain section immunolabeled for PDGF- $\alpha \mathrm{R}(C)$ and GFAP $(D)$. Arrowheads in $C$ indicate PDGF- $\alpha$ R-positive cells that do not express GFAP in $D$. P7 sagittal brain section through the cerebral cortex stained for PDGF- $\alpha \mathrm{R}(E)$ and MAP2 $(F)$. Neurons (arrowheads) stained with the anti-MAP2 antibody $(E)$ express PDGF- $\alpha \mathrm{R}(F)$. Magnification, 224×.

served in this PDGF- $\alpha \mathrm{R}^{+}$cell type. In contrast, a colocalization of Rip and PDGF- $\alpha \mathrm{R}$ was observed in this cell type (Fig. 6A,B), demonstrating that these cells are premyelinating oligodendrocytes. Strict colocalization between PDGF- $\alpha \mathrm{R}$ and Rip expression was frequently not observed, thus suggesting that these PDGF$\alpha \mathrm{R}^{+}$cells could also be more immature cells of the oligodendro- cyte lineage. Mature oligodendrocytes were not found to express PDGF- $\alpha \mathrm{R}$ once myelination was complete, arguing in favor of downregulation of PDGF- $\alpha \mathrm{R}$ expression in oligodendrocytes in correlation with their differentiation and myelinating behavior. In the adult mouse CNS, the oligodendroglial expression of the PDGF- $\alpha$ R was considerably decreased. Very few oligodendroglial 

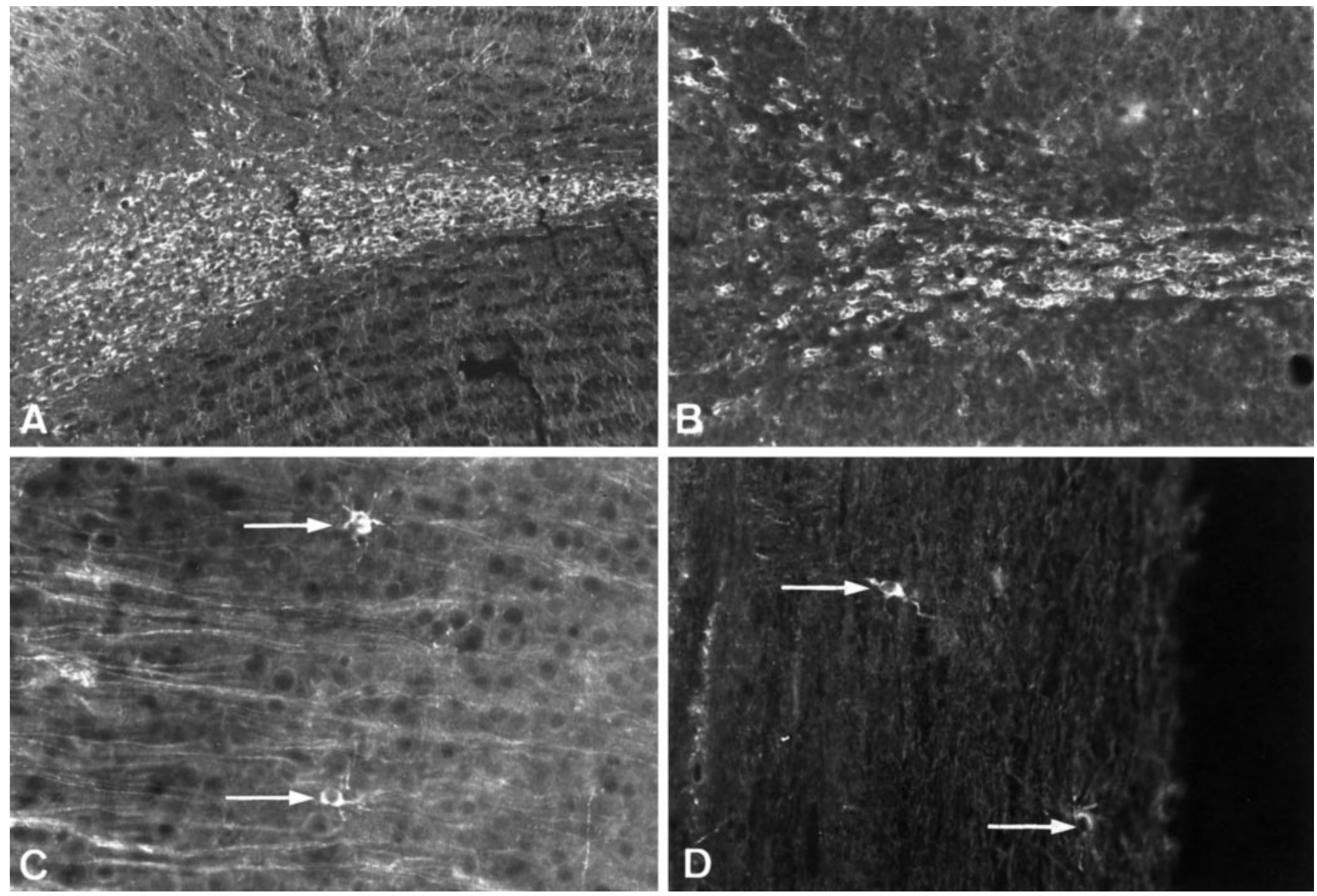

Figure 7. Immunodetection of PDGF- $\alpha \mathrm{R}$ in stem cells and oligodendrocyte progenitors of the adult mouse CNS. Neural stem cells of the subependymal/ ependymal layer of the olfactory bulb are stained for PDGF- $\alpha \mathrm{R}(A)$. These cells also express PSA-NCAM $(B$, adjacent section). In the adult CNS, very few oligodendrocyte progenitors (arrows) stained with the anti-PDGF- $\alpha \mathrm{R}$ antibody were detected in the cerebral cortex $(C)$ and spinal cord white matter (D). Magnification, 200×.

progenitors were immunologically detected in the cerebral cortex (Fig. $7 C$ ) or in the spinal cord white matter (Fig. 7D). Cells located around the subventricular zone of the lateral ventricle and the ependymal/subependymal layer of the olfactory ventricle were labeled with the anti-PDGF- $\alpha \mathrm{R}$ antibody (Fig. 7A). These cells, stained with the anti-Men $\mathrm{B}$ antibody raised specifically against the embryonic form of N-CAM (Fig. 7B), are the migrating neural stem cells described recently by Lois and Alvarez-Buylla (1994) and Rousselot et al. (1995).

\section{Persistent expression of PDGF- $\alpha$ R proteins and transcripts in neurons of the adult mouse CNS}

The most striking observation in our study is that PDGF- $\alpha \mathrm{R}$ protein and transcripts were mainly localized in mature neurons. The neuronal distribution of the PDGF- $\alpha \mathrm{R}$ immunoreactivity is indicated in Table 1 and is illustrated for several regions of the adult mouse CNS (see Figs. 8, 9). In the olfactory bulb, PDGF- $\alpha$ R immunoreactivity was localized in neurons of the mitral layer as well as on neurites of the external plexiform layer (not shown). In pyramidal neurons of cerebral cortex layer $\mathrm{V}$, the receptor was mainly present on the axons and weakly present in the cytoplasm (Fig. $8 A$ ). In the hippocampus, pyramidal neurons of the CA1-CA3 regions and granule neurons of the dentate gyrus were strongly immunolabeled (Fig. $8 B$ ). In the subiculum, PDGF- $\alpha \mathrm{R}$ immunoreactivity was ob- served principally on the axons (Fig. $8 C$ ), whereas in the globus pallidus (Fig. $8 D$ ) and substantia nigra (Fig. $8 E, F$ ), PDGF- $\alpha \mathrm{R}$ protein was mainly localized in the neuronal cell bodies. In the adult cerebellum, Purkinje cells (Fig. 9A) as well as deep cerebellar nuclei neurons were strongly immunolabeled with anti-PDGF- $\alpha \mathrm{R}$ (Fig. 9C,D). In the Purkinje cell layer, the immunoreactivity was always localized in the soma and the dendritic tree, whereas their axons remained constantly unlabeled, as in the molecular and granule cell layer (Fig. 9B). Most brainstem nuclei, like the facial nucleus (Fig. 9E), highly expressed the PDGF- $\alpha \mathrm{R}$. In this nucleus, the immunolabeling was observed in the neuronal cytoplasm, on dendrites, and on the initial segment of axons (Fig. $9 F$ ). In the adult mouse spinal cord, the expression of PDGF- $\alpha \mathrm{R}$ was mainly detected in neurons of the dorsal horn and motoneurons of the ventral horn (see Table 1). In control experiments, the same pattern of immunoreactivity for PDGF- $\alpha \mathrm{R}$ was also observed on adult rat brain floating sections (data not shown), thus confirming that the neuronal expression of PDGF- $\alpha \mathrm{R}$ was not related to species differences between mice and rats. Moreover, immunolabeling performed on adult mouse brain with the PDGFR-7 antibody, raised against the cytoplasmic domain of human PDGF- $\alpha$ R (Eriksson et al., 1992), clearly confirmed the localization of the PDGF- $\alpha \mathrm{R}$ on neurons (data not shown). 

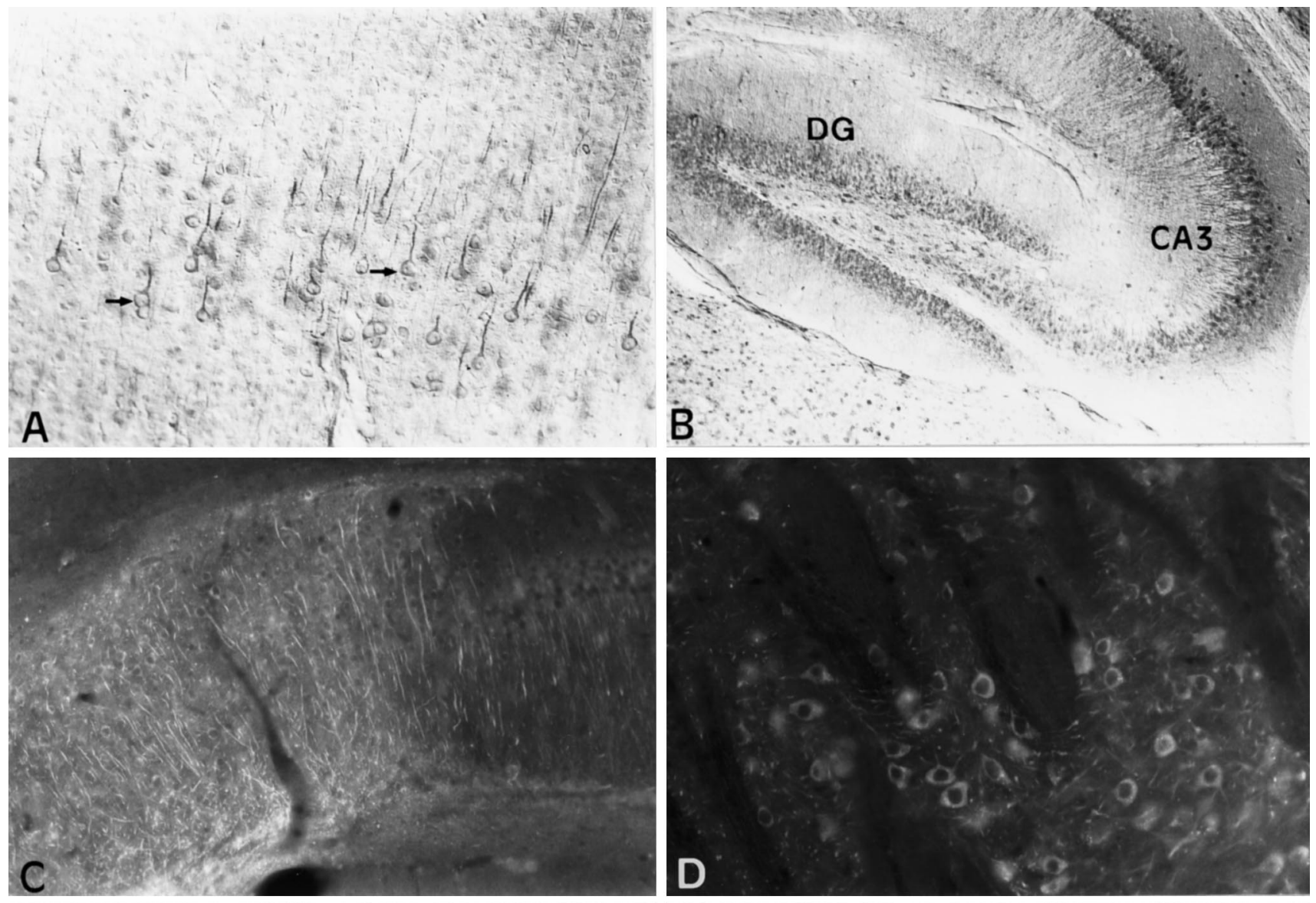

B
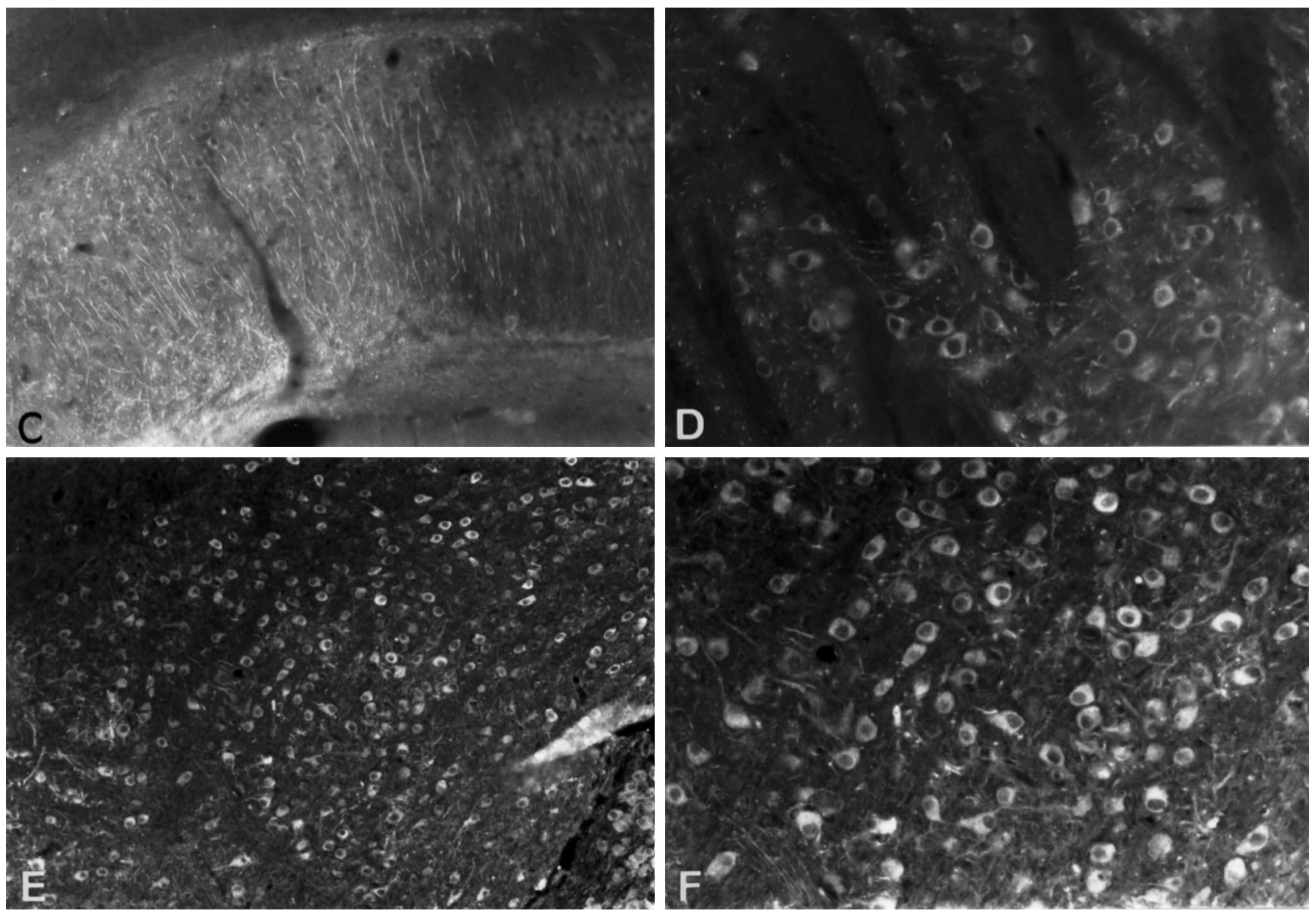

Figure 8. Localization of PDGF- $\alpha \mathrm{R}$ immunoreactivity in the adult mouse brain. Immunodetection of the PDGF- $\alpha \mathrm{R}$ protein in neurons (arrows) of the cerebral cortex $(A)$, hippocampus $(B)$, subiculum $(C)$, globus pallidus $(D)$, and substantia nigra $(E)$. High-power view of PDGF- $\alpha$ R-positive neurons of the substantia nigra pars reticulata showing the localization of the protein in the neuronal cell bodies, dendrites, and initial segment of the axons $(F)$. $A$, $B$, Immunoperoxidase; $C, D-F$, immunofluorescence. $D G$, Dentate gyrus; $C A 3$, hippocampal field. Magnification: $A, B, C, E, 124 \times ; D, F, 248 \times$.

In view of the wide distribution of $\mathrm{PDGF}-\alpha \mathrm{R}$ protein observed in mature neurons, we proceeded to look for a constitutive expression of the PDGF- $\alpha \mathrm{R}$ gene in this cell population. PDGF- $\alpha \mathrm{R}$ gene expression in the adult brain was assayed by in situ hybridization using a PDGF- $\alpha \mathrm{R}$ antisense oligonucleotide probe end-labeled with digoxigenin. Figure 10 illustrates the presence of PDGF- $\alpha$ R mRNA in adult mouse brain sections. PDGF- $\alpha \mathrm{R}$ transcripts were detected in neurons of several regions, including the hippocampus (Fig. 10A), subiculum and entorhinal cortex (Fig. 10B), substantia nigra (Fig. 10C), Purkinje cell layer of the cerebellum (Fig. 10D), and the vestibular nucleus (Fig. 10E). We also observed PDGF- $\alpha \mathrm{R}$ mRNA in neurons of the olfactory bulb, cerebral cortex, and the thalamus, whereas a specific in situ hybridization signal was not detected in any striatal neurons (not shown). PDGF- $\alpha \mathrm{R}$ transcripts were not detected in white matter structures, as in the corpus callosum (Fig. 10A,B). Control brain tissue sections, hybridized with the PDGF- $\alpha \mathrm{R}$ sense oligonucleotide probe 

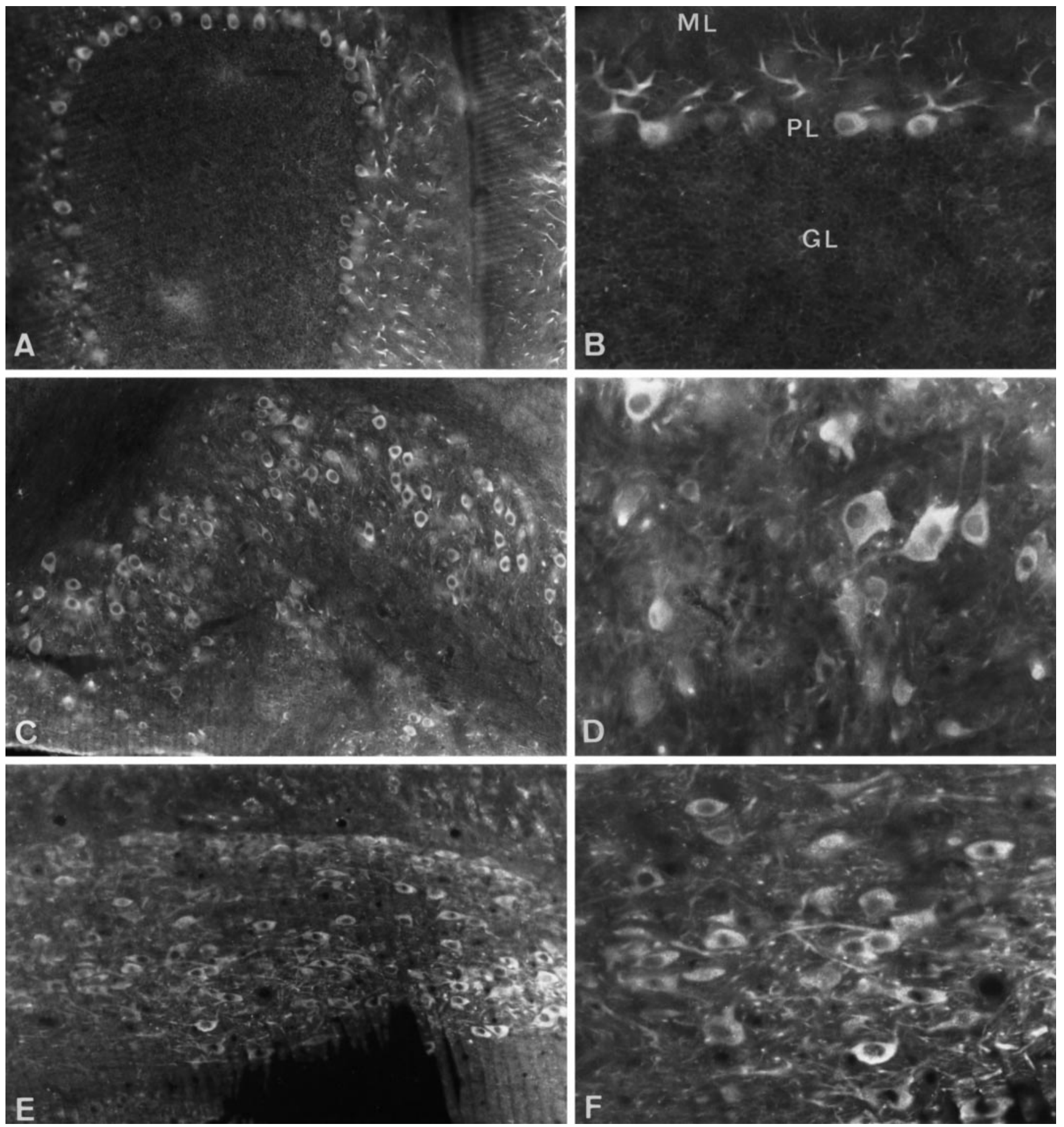

Figure 9. Expression of PDGF- $\alpha \mathrm{R}$ in the adult cerebellum and brainstem nuclei. In the adult cerebellum, the expression of PDGF- $\alpha \mathrm{R}$ is detected only in the Purkinje cell layer $(P L)$, whereas the molecular $(M L)$ and granule cell layers $(G L)$ remained unstained with the anti-PDGF- $\alpha$ R $(A)$. $B$, High-magnification view of the immunoreactivity in the soma and dendritic processes of Purkinje cells. Note that PDGF- $\alpha$ R immunoreactivity is not found in Purkinje cell axons. $C$, Immunodetection of PDGF- $\alpha \mathrm{R}$ in neurons of the interpositus cerebelli nucleus. $D$, High-power view of PDGF- $\alpha$ R-positive neurons of the interpositus cerebelli nucleus. $E$, PDGF- $\alpha$ R immunoreactivity in the facial nucleus. $F$, High-magnification view of the staining of facial nucleus neurons. Magnification: $A, C, 110 \times ; B, D, 220 \times ; E, 130 \times ; F, 260 \times$.

end-labeled with digoxigenin, were always free of mRNA signal (Fig. 10F). The same result was obtained by digestion of the cellular signal with RNase A before the hybridization step or by competition with a 40 -fold excess unlabeled probe in the hybridization mixture. The presence of PDGF- $\alpha$ R protein and transcripts in the same CNS structures argues in favor of a constitutive expression of this receptor by neurons.

\section{DISCUSSION}

The present findings illustrate for the first time the presence of the PDGF- $\alpha \mathrm{R}$ in neurons during postnatal development of the mouse CNS. The expression of this receptor is detected in neurons as early as P1 and persists throughout adulthood. Our data also demonstrate that the prominent expression of PDGF- $\alpha \mathrm{R}$ in oli- 


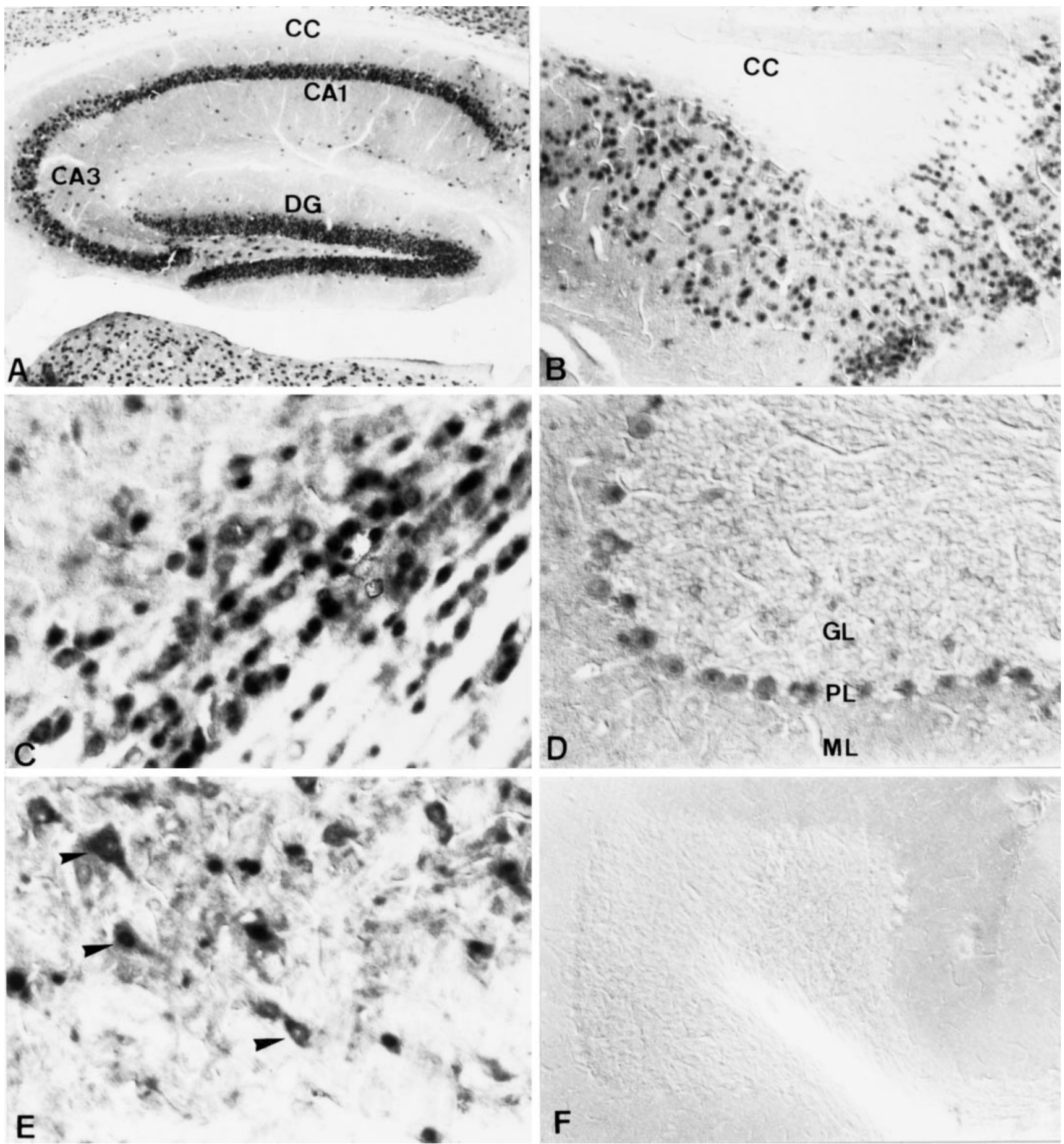

Figure 10. Detection of PDGF- $\alpha$ R transcripts in the adult mouse CNS by nonradioactive in situ hybridization. PDGF- $\alpha$ R mRNA are widely expressed in neuronal populations, as illustrated for the hippocampus $(A)$, subiculum and entorhinal cortex $(B)$, substantia nigra pars compacta $(C)$, Purkinje cell layer of the cerebellum $(D)$, and neurons of the vestibular nucleus $(E)$. Hybridization signal is not observed in white matter structures, such as the corpus callosum $(A, B) . F$, Control in situ hybridization with the PDGF- $\alpha \mathrm{R}$ digoxigenin-labeled oligonucleotide sense probe performed on sagittal brain tissue section through the cerebellum. $A-F$, Bright-field and phase-contrast. $D G$, Dentate gyrus; $C A 1, C A 3$, hippocampal fields; $C C$, corpus callosum; $M L$, molecular layer; $P L$, Purkinje cell layer; $G L$, granule cell layer. Magnification: $A, 110 \times ; B, D, F, 220 \times ; C, E, 300 \times$.

godendrocyte progenitor cells during myelination is downregulated in the adult CNS, as demonstrated previously (Reddy and Pleasure, 1992; Yeh et al., 1993; Ellison and de Vellis, 1994). Although the expression of PDGF- $\alpha \mathrm{R}$ is commonly attributed to the $\mathrm{O}-2 \mathrm{~A}$ progenitors, the unexpected neuronal expression reported in this study leads us to speculate on possible neurotrophic effects of PDGF in the CNS.

\section{Concomitant expression of the PDGF- $\alpha$ R by neurons and immature cells of the oligodendrocyte lineage during postnatal development}

Our results show, as do several other studies, the expression of PDGF- $\alpha$ R by immature cells of the oligodendrocyte lineage in the developing CNS (Pringle et al., 1992, Yeh et al., 1993; Ellison and de Vellis, 1994). The oligodendroglial expression is mainly ob- 
served around subventricular germinal zones and spreads out to most brain regions during myelination. Indeed, the pattern of PDGF- $\alpha \mathrm{R}$ expression is well correlated with the development of the $\mathrm{O}-2 \mathrm{~A}$ cells in the anterior forebrain, as observed by IHC for GD3 (LeVine and Goldman, 1988a,b) or by in vivo retroviral labeling of the SVZ progenitors (Levison and Goldman, 1993; Luskin and McDermott, 1994; Zerlin et al., 1995). In vivo, PDGF-A and -B chains are widely expressed by neurons of the embryonic and adult CNS (Sasahara et al., 1991; Yeh et al., 1991) and type-1 astrocytes (Richardson et al., 1988; Yeh et al., 1991), suggesting that neurons, in addition to astrocytes, could direct targeting, proliferation, and differentiation of the oligodendroglial progenitors before myelination. Neuronal control of oligodendrocyte development has been suggested recently by several studies (Hardy and Reynolds, 1993; Barres and Raff, 1994; Burne et al., 1996).

The present paper also demonstrates the localization of PDGF- $\alpha \mathrm{R}$ in most neurons during early postnatal development, arguing for a more extended role of this receptor than has been described previously. PDGF- $\alpha \mathrm{R}$ is present on most neurons as early as P1 and persists in the adult CNS. During the first postnatal week of development, PDGF- $\alpha \mathrm{R}$ immunoreactivity is mainly found on unmyelinated neurites, suggesting that this expression could be involved in neurite outgrowth (Fanger et al., 1995). This idea is supported by the presence of PDGF-A chain in the growth cones of neurons in mid-embryonic brain development (Hutchins and Jefferson, 1992). The involvement of PDGF- $\alpha \mathrm{R}$ during development was suggested previously by analysis of the Patch mutation, a deletion of the PDGF- $\alpha$ R. Patch mouse embryos display obvious growth retardation and deficiencies in mesodermal structures, and late embryonic defects were associated with both mesodermal and neural crest derivatives (MorrisonGraham et al., 1992; Orr-Urtreger et al., 1992; Schatteman et al., 1992). Our results, demonstrating an expression of PDGF- $\alpha$ R by neurons in the developing and mature CNS, also argue for a crucial role of this receptor in the normal development of the CNS. Its expression by neurons could be necessary for their differentiation and/or maturation. For instance, in the developing cerebellum, granule cells expressed the PDGF- $\alpha \mathrm{R}$ during their maturation and migration toward the molecular and Purkinje cell layers, whereas Purkinje cells constitutively expressed this tyrosine kinase receptor.

Earlier data reporting a restricted expression of PDGF- $\alpha \mathrm{R}$ on oligodendroglia failed to detect its expression on neurons (Pringle et al., 1992; Yeh et al., 1993). However, in these studies the expression of PDGF- $\alpha$ R was investigated by in situ hybridization, and the cell types expressing PDGF- $\alpha \mathrm{R}$ were identified solely on the basis of the shape and size of their nucleus. However, Pringle and Richardson (1993) showed, between E12.5 and E15, a transient expression of PDGF- $\alpha \mathrm{R}$ transcripts by presumptive neuronal precursors near the dorsal alar ventricular zone of the rat spinal cord. Moreover, other studies have shown the localization of PDGF- $\alpha \mathrm{R}$ in neurons of the rat dorsal root ganglion at all stages of postnatal development (Eccleston et al., 1993) and in cultured rodent embryonic hippocampal and cortical neurons (Cheng and Mattson, 1995; Hutchins, 1995). Immunohistological and in situ hybridization analyses of the developmental expression of PDGF- $\alpha$ R reported in this study clearly demonstrate the expression of PDGF- $\alpha$ R by neurons. This result, also obtained with the PDGFR-7 antibody raised against the cytoplasmic domain of human PDGF- $\alpha \mathrm{R}$ (Eriksson et al., 1992), firmly establishes the specificity of this neuronal expression in rat and mouse CNS and excludes both antibodies and species-related specificity. The differences in results between previous studies and the present study could be related to the highly sensitive IHC procedure involving free-floating sections. Indeed, PDGF- $\alpha \mathrm{R}$ immunolabeling on neurons was very weak and was not observed in brain structures, such as the substantia nigra, the hippocampus, and the thalamus, when frozen brain tissue sections were used in this study. Neuronal expression of PDGF- $\alpha \mathrm{R}$ is low in comparison with oligodendroglial expression and could have been missed on frozen tissue sections.

\section{Differential regulation of PDGF- $\alpha R$ expression in neurons and oligodendrocyte progenitors}

Our data emphasize a differential regulated expression of PDGF- $\alpha \mathrm{R}$ in neurons and oligodendrocyte progenitors. In the adult CNS, the synthesis of PDGF- $\alpha \mathrm{R}$ persists in numerous neuronal populations, whereas in oligodendrocytes, this expression was downregulated in correlation with their differentiation. In the mature $\mathrm{CNS}$, the expression of PDGF- $\alpha \mathrm{R}$ was detected in very few oligodendrocyte progenitors scattered throughout white matter structures and the cerebral cortex. These rare cells, with a morphology analogous to that observed during development, could be the $\mathrm{O}-2 \mathrm{~A}^{\text {adult }}$ progenitors isolated from adult tissue (Wolswijk et al., 1991). These cells have also been immunologically characterized by coexpression of PDGF- $\alpha \mathrm{R}$ and NG2 proteoglycan (Nishiyama et al., 1996). In vitro, PDGF is mitogenic for $\mathrm{O}-2 \mathrm{~A}^{\text {adult }}$ progenitor cells, and cooperation between PDGF and b-FGF converts these slowly dividing progenitors to rapidly dividing cells with characteristics of $\mathrm{O}-2 \mathrm{~A}^{\text {perinatal }}$ progenitors (Wolswijk and Noble, 1992). In vivo, it is plausible that these cells may be responsible for the generation of new oligodendrocytes after myelin damage (for review, see Wood and Mora, 1993). However, the involvement of these progenitors in remyelination and their response to demyelination remain to be analyzed. In the adult CNS, PDGF- $\alpha$ R is also detected in neural stem cells of subventricular zones, such as the SVZ of the lateral ventricle and the subependymal/ependymal layer of the olfactory ventricle. These cells would mainly represent migrating neural precursors, which generate neurons of the olfactory bulb (Lois and Alvarez-Buylla, 1993, 1994; Luskin, 1993; Rousselot et al., 1995). PDGF, in addition to other proposed molecules such ECM molecules or the embryonic form of N-CAM (Gates et al., 1995), could regulate the migration and differentiation of neural stem cells of the adult CNS.

\section{PDGF- $\alpha$ R activation could mediate instructive, survival, and neurotrophic effects in the CNS}

Several studies have mentioned neurotrophic, instructive, and neuroprotective effects of PDGF on cultured immature neurons, mediated through the activation of the two forms of PDGF receptors (Nikkhah et al., 1993; Smits et al., 1993; Cheng and Mattson et al., 1995; Fanger et al., 1995). For instance, PDGF-BB exerts trophic activity on cultured GABAergic interneurons by increasing the expression of glutamic acid decarboxylase (GAD) and the survival of these cells (Smits et al., 1993). PDGF promotes survival of rat and human mesencephalic dopaminergic neurons in culture (Nikkhah et al., 1993) and, in vitro, induces neurite outgrowth of the PC12 neuronal cell line (Fanger et al., 1995). The fact that neurons express PDGF- $\alpha \mathrm{R}$ during development and in the adult rodent CNS is in agreement with the trophic effects reported for PDGF. These neurotrophic effects may be mediated via the neuronal expression of PDGF- $\alpha$ R. Moreover, PDGF 
treatment of cultured fibroblast leads to the activation of the voltage-gated calcium channel and to subsequent calcium influx (Estacion and Moran, 1993). In neurons, similar mechanisms could regulate neuritic outgrowth and/or neurotransmitter release. More recently, Cheng and Mattson (1995) also reported that PDGF protect embryonic hippocampal neurons against energy deprivation and oxidative injury in vitro, by increasing the activity of antioxidative enzymes like catalase and glutathione peroxidase. Furthermore, PDGF induces phosphorylation of the mitochondrial $\mathrm{F}_{1} \mathrm{~F}_{0}$ ATPase $\delta$ subunit in mouse cortical neurons in vitro (Zhang et al., 1995). The expression of both PDGF- $\alpha \mathrm{R}$ and PDGF- $\beta$ R by neurons and the fact that both PDGF-AA and PDGF-BB were effective in protecting these cells strongly suggest that either $\alpha$ receptors or $\beta$ receptors can trigger neuroprotective mechanisms. Thus, the expression of this receptor in mature neurons could have a physiological role in the normal functioning of neurons in vivo.

These findings definitively demonstrate that the PDGF- $\alpha \mathrm{R}$ have a more extended distribution than reported previously. This observation suggests that, during early postnatal development, PDGF could play a role not only in the control of oligodendroglial population but also in the maturation of neurons and could have a survival or neurotrophic effect on neurons. The physiological functions of the neuronal synthesis of PDGF- $\alpha \mathrm{R}$ remain, however, to be determined.

\section{REFERENCES}

Altman J (1972) Postnatal development of the cerebellar cortex in the rat. III. Maturation of the components of the granular layer. J Comp Neurol 145:465-514.

Antoniades HN (1981) Human platelet-derived growth factor: purification of PDGF-I and PDGF-II and separation of their reduced subunits. Proc Natl Acad Sci USA 78:7314-7317.

Armstrong RC, Harvath L, Dubois-Dalcq ME (1990) Type 1 astrocytes and oligodendrocyte-type 2 astrocyte glial progenitors migrate toward distinct molecules. J Neurosci Res 27:400-407.

Austyn JM, Gordon S (1981) F4/80: a monoclonal antibody directed specifically against the mouse macrophage. Eur J Immunol 11:805-815.

Barres BA, Raff MC (1993) Proliferation of oligodendrocyte precursor cells depends on electrical activity of axons. Nature 361:258-260.

Barres BA, Raff MC (1994) Control of oligodendrocyte number in the developing rat optic nerve. Neuron 12:935-942.

Bauer EA, Cooper TW, Huang JS, Altman J, Deuel TF (1985) Stimulation of in vitro human skin collagenase expression by platelet-derived growth factor. Proc Natl Acad Sci USA 82:4132-4136.

Besnard F, Perraud F, Sensenbrenner M, Labourdette G (1987) Plateletderived growth factor is a potent mitogen for glial cell but not neuronal rat brain cells in vitro. Neurosci Lett 73:287-292.

Brevitt B, Clark JJ (1988) Growth and transparency in the lens, an epithelial tissue, stimulated by pulses of PDGF. Science 242:777-779.

Burne J, Staple JK, Raff MC (1996) Glial cells are increased proportionally in transgenic optic nerves with increased numbers of axons. J Neurosci 16:2064-2073.

Cheng B, Mattson M (1995) PDGFs protect hippocampal neurons against energy deprivation and oxidative injury: evidence for induction of antioxidant pathways. J Neurosci 15:7095-7104.

Chua CC, Gieman DE, Keller DH, Ladda RL (1995) Induction of collagenase secretion in human fibroblasts culture by growth promoting factors. J Biol Chem 260:5213-5216.

Eccleston PA, Funa K, Heldin CH (1993) Expression of platelet-derived growth factor (PDGF) and PDGF $\alpha$ - and $\beta$-receptors in the peripheral nervous system: an analysis of sciatic nerve and dorsal root ganglia. Dev Biol 155:459-470.

Ellison JA, de Vellis J (1994) Platelet-derived growth factor receptor is expressed by cells in the early oligodendrocyte lineage. J Neurosci Res 37:116-128.

Eriksson A, Siegbahn A, Westermark B, Heldin CH, Claesson-Welsh L (1992) PDGF $\alpha$ - and $\beta$-receptors active unique and common signal transduction pathways. EMBO J 11:543-550.
Estacion M, Mordan LJ (1993) Expression of voltage-gated calcium channels correlates with PDGF-stimulated calcium influx and depends upon cell density in $\mathrm{C} 3 \mathrm{H} 10 \mathrm{~T} 1 / 2$ mouse fibroblasts. Cell Calcium 14:161-171.

Fanger GR, Jones JR, Maue RA (1995) Differential regulation of neuronal sodium channel expression by endogenous and exogenous tyrosine receptors expressed in rat pheochromocytoma cells. J Neurosci 15:201-213.

Foran DR, Peterson AC (1992) Myelin acquisition in the central nervous system revealed by an MBP-Lac Z transgene. J Neurosci 12:4890-4897.

Friedman B, Hockfield S, Black JA, Woodruff KA, Waxman SG (1989) In situ demonstration of mature oligodendrocytes and their processes: An immunohistochemical study with a new monoclonal antibody, Rip. Glia 2:380-390.

Gates MA, Thomas LB, Howard EM, Laywell ED, Sajin B, Faissner A, Götz B, Silver J, Steindler DA (1995) Cell and molecular analysis of the developing and adult mouse subventricular zone of the cerebral hemispheres. J Comp Neurol 361:249-266.

Grotendorst GR, Chang T, Seppä HEJ, Kleinman HK, Martin GR (1982) Platelet-derived growth factor is a chemoattractant for vascular smooth muscle cells. J Cell Physiol 113:261-266.

Hardy R, Reynolds R (1993) Rat cerebral cortical neurons in primary culture release a mitogen specific for early $\left(\mathrm{GD}^{+} / \mathrm{O}^{-}\right)$oligodendroglial progenitors. J Neurosci Res 34:589-600.

Heldin CH, Westermark B (1990) Platelet-derived growth factor: mechanism of action and possible in vivo function. Cell Regul 1:555-566.

Hosang M, Rouge M, Wipf B, Eggiman B, Kaufmann F, Hunziker W (1989) Both homodimeric isoforms of PDGF (AA and BB) have mitogenic and chemotactic activity and stimulate phosphoinositol turnover. J Cell Physiol 140:558-564.

Hutchins JB (1995) Platelet-derived growth factor of mouse central nervous system cells in vitro. J Comp Neurol 360:59-80.

Hutchins JB, Jefferson VE (1992) Developmental distribution of platelet-derived growth factor in the mouse central nervous system. Dev Brain Res 67:121-135.

Jahveri S, Erzurumlu RS, Friedman B, Schneider GE (1992) Oligodendrocytes and myelin formation along the optic nerve tract of the developing hamster: an immunohistochemical study using the Rip antibody. Glia 6:138-148.

LeVine SM, Goldman JE (1988a) Spatial and temporal patterns of oligodendrocyte differentiation in rat cerebrum and cerebellum. J Comp Neurol 277:441-455.

LeVine SM, Goldman JE (1988b) Embryonic divergence of oligodendrocyte and astrocyte lineages in developing rat cerebrum. J Neurosci 8:3992-4006.

Levison SW, Goldman JE (1993) Both oligodendrocytes and astrocytes develop from progenitors in the subventricular zone of postnatal rat forebrain. Neuron 10:201-212.

Lillien LE, Sendtner M, Rohrer H, Hughes SM, Raff MC (1988) Type-2 astrocyte development in rat brain cultures is initiated by a CNTF-like protein produced by type-1 astrocytes. Neuron 1:485-494.

Lois C, Alvarez-Buylla A (1993) Proliferating subventricular zone cells in the adult mammalian forebrain can differentiate into neurons and glia. Proc Natl Acad Sci USA 90:2074-2077.

Lois C, Alvarez-Buylla A (1994) Long-distance neuronal migration in the adult brain. Science 264:1145-1148.

Luskin MB (1993) Restricted proliferation and migration of postnatally generated neurons derived from the forebrain subventricular zone. Neuron 11:173-189.

Luskin MB, McDermott K (1994) Divergent lineages for oligodendrocytes and astrocytes originating in the neonatal forebrain subventricular zone. Glia 11:211-226.

Majack RA, Mildbrandt J, Dixit VM (1987) Induction of thrombospondin messenger RNA levels occurs as an immediate primary response to platelet-derived growth factor. J Biol Chem 262:8821-8825.

Matsui T, Heidaran M, Miki T, Popescu N, LaRochelle W, Kraus M, Pierce J, Aaronson S (1989) Isolation of a novel receptor cDNA establishes the existence of two PDGF receptor genes. Science 243:800-804.

McKinnon RD, Matsui T, Dubois-Dalcq M, Aaronson SA (1990) FGF modulates the PDGF-driven pathway of oligodendrocyte development. Neuron 5:603-614.

McKinnon RD, Piras G, Ida JA, Dubois-Dalcq M (1993) A role of TGF- $\beta$ in oligodendrocyte differentiation. J Cell Biol 121:1397-1407. 
Mellström K, Heldin CH, Westermark B (1988) Induction of circular membrane ruffling on human fibroblasts by platelet-derived growth factor. Exp Cell Res 177:347-359.

Mercola M, Wang C, Kelly J, Brownlee C, Jackson-Grusby L, Stiles C, Bowen-Pope DF (1990) Selective expression of PDGF A and its receptor during early mouse embryogenesis. Dev Biol 138:114-122.

Morrison-Graham K, Schatteman GC, Bork T, Bowen-Pope DF, Weston J (1992) A PDGF receptor mutation in the mouse (Patch) perturbs the development of a non-neuronal subset of neural crest-derived cells. Development 115:133-142.

Narayanan AS, Page RC (1983) Biosynthesis and regulation of type V collagen in diploid human fibroblasts. J Biol Chem 258:1164-11699.

Nikkhah G, Odin P, Smits A, Tingström A, Othberg A, Brundin P, Funa K, Lindvall O (1993) Platelet-derived growth factor promotes survival of rat and human mesencephalic dopaminergic neurons in culture. Exp Brain Res 92:516-523.

Nishiyama A, Lin XH, Giese N, Heldin CH, Stallcup WB (1996) Colocalization of NG2 preoteoglycan and PDGF $\alpha$-receptor on O-2A progenitor cells in the developing rat brain. J Neurosci Res 43:299-314.

Noble M, Murray K, Stroobant P, Waterfield MD, Ridle P (1988) Platelet-derived growth factor promotes division and motility and inhibits premature differentiation of the oligodendrocyte/type-2 astrocyte progenitor cell. Nature 333:560-562.

Orr-Urtreger A, Bedford MT, Do MS, Eisenbach L, Lonai P (1992) Developmental expression of the $\alpha$ receptor for platelet-derived growth factor, which is deleted in the embryonic lethal Patch mutation. Development 115:289-303.

Pringle NP, Richardson WD (1993) A singularity of PDGF $\alpha$-receptor expression in the dorsoventral axis of the neural tube may define the origin of the oligodendrocyte lineage. Development 117:525-533.

Pringle NP, Collarini EJ, Mosley MJ, Heldin CH, Westermark B, Richardson WD (1989) PDGF A chain homodimers drive the proliferation of bipotential (O-2A) glial progenitors cells in the developing rat optic nerve. EMBO J 4:1049-1056.

Pringle NP, Mudhar HS, Collarini EJ, Richardson WD (1992) PDGF receptors in the rat CNS: during late neurogenesis, PDGF $\alpha$-receptor expression appears to be restricted to glial cells of the oligodendrocyte lineage. Development 115:535-551.

Raff MC, Lillien LE, Richardson WD, Burne JF, Noble M (1988) Platelet-derived growth factor from astrocytes drives the clock that times oligodendrocyte development in culture. Nature 333:562-565.

Reddy UR, Pleasure D (1992) Expression of platelet-derived growth factor (PDGF) and PDGF receptor genes in the developing rat brain. J Neurosci Res 31:670-677.

Richardson WD, Pringle N, Mosley MJ, Westermark B, Dubois-Dalcq M (1988) A role for PDGF in normal gliogenesis in the central nervous system. Cell 53:309-319.

Ross R, Glomet J, Kariya B, Harker L (1974) A platelet-dependent serum factor that stimulate the proliferation of arterial smooth muscle cells in vitro. Proc Natl Acad Sci USA 71:1207-1210.

Rougon G, Dubois C, Buckley N, Magnani JL, Zollinger W (1986) A mouse monoclonal antibody against meningococcus group $\mathrm{B}$ polysaccharides distinguishes embryonic form from adult N-CAM. J Cell Biol 103:2429-2437.

Rousselot P, Lois C, Alvarez-Buylla A (1995) Embryonic (PSA) N-CAM reveals chains of migrating neuroblasts between the lateral ventricle and the olfactory bulb of adult mice. J Comp Neurol 351:51-61.
Sasahara M, Fries JWU, Raines EW, Grown AM, Westrum LE, Frosch MP, Bonthron DT, Ross R, Collins T (1991) PDGF-B chains in neurons of the central nervous system, posterior pituitary and in transgenic model. Cell 64:217-227.

Schatteman GC, Morrison-Graham K, Van Koppen A, Weston JA, Bowen-Pope DF (1992) Regulation and role of PDGF receptor $\alpha$-subunit expression during embryogenesis. Development 115:123-131.

Shimokado K, Raines EW, Madtes DK, Barett TB, Benditt EP, Ross R (1985) A significant part of macrophage-derived growth factor consists of at least two forms of PDGF. Cell 43:277-286.

Smits A, Ballagi E, Funa K (1993) PDGF-BB exerts trophic activity on cultured GABA interneurons from the newborn rat cerebellum. Eur J Neurosci 5:986-994.

Timsit SG, Martinez S, Allinquant B, Peyron F, Puelles L, Zalc B (1995) Oligodendrocytes originate in a restricted zone of the embryonic ventral neural tube defined by DM-20 mRNA expression. J Neurosci 15:1012-1024.

Ullrich A, Schlessinger J (1990) Signal transduction by receptors with tyrosine kinase activity. Cell 61:203-212.

Vignais L, Nait Oumesmar B, Baron-Van Evercooren A (1995) PDGF $\alpha$-receptor is expressed by mature neurons of the mouse central nervous system. NeuroReport 15:1993-1996.

Wang Z, Estacion M, Mordan LJ (1993) $\mathrm{Ca}^{2+}$ influx via T-type channels modulates PDGF-induced replication of mouse fibroblasts. Am J Physiol 265:1239-1246.

Westermark B, Wasteson A (1976) A platelet factor stimulating human normal glial cells. Exp Cell Res 98:170-174.

Wolswijk G, Noble M (1992) Cooperation between PDGF and FGF converts slowly dividing $\mathrm{O}-2 \mathrm{~A}^{\text {adult }}$ progenitor cells to rapidly dividing cells with characteristics of $\mathrm{O}-2 \mathrm{~A}^{\text {perinatal }}$ progenitor cells. J Cell Biol 118:889-900.

Wolswijk G, Riddle PN, Noble M (1991) Platelet-derived growth factor is mitogenic for $\mathrm{O}-2 \mathrm{~A}^{\text {adult }}$ progenitor cells. Glia 4:495-503.

Wood PM, Mora J (1993) Source of remyelinating oligodendrocytes. Adv Neurol 59:113-123.

Yarden Y, Ullrich A (1988) Growth factor receptor tyrosine kinases. Annu Rev Biochem 54:443-478.

Yeh HJ, Ruit KG Wang YX, Parks WC, Snider WD, Deuel TF (1991) PDGF A-chain gene is expressed by mammalian neurons during development and in maturity. Cell 84:209-216.

Yeh HJ, Silos-Santiago I, Wang YX, Parks WC, George RJ, Snider WD, Deuel TF (1993) Developmental expression of the platelet-derived growth factor $\alpha$-receptor gene in mammalian central nervous system. Proc Natl Acad Sci USA 90:1952-1956.

Yu WP, Collarini EJ, Pringle NP, Richardson WD (1994) Embryonic expression of myelin genes: evidence for a focal source of oligodendrocyte precursors in the ventricular zone of the neural tube. Neuron 12:1353-1362.

Zerlin M, Levison SW, Goldman JE (1995) Early patterns of migration, morphogenesis and intermediate filament expression of subventricular zone cells in the postnatal rat forebrain. J Neurosci 15:7238-7249.

Zhang FX, Pan W, Hutchins JB (1995) Phosphorylation of F1/F0 ATPase $\delta$-subunit is regulated by Platelet-derived growth factor in mouse cortical neurons in vitro. J Neurochem 65:2812-2815. 